OPEN ACCESS

Edited by:

Kutty Selva Nandakumar, Southern Medical University, China

Reviewed by:

Guenter Steiner,

Medical University of Vienna, Austria

Balik Dzhambazov,

Plovdiv University "Paisi

Hilendarski", Bulgaria

${ }^{*}$ Correspondence:

Sung-Hwan Park

rapark@catholic.ac.kr

Mi-La Cho

iammila@catholic.ac.kr

†These authors have contributed equally to this work

Specialty section

This article was submitted to Autoimmune and Autoinflammatory Disorders,

a section of the journal

Frontiers in Immunology

Received: 22 March 2019

Accepted: 09 September 2019

Published: 04 October 2019

Citation:

Park J-S, Moon S-J, Lim M-A

Byun J-K, Hwang S-H, Yang $S$, Kim E-K, Lee H, Kim S-M, Lee J,

Kwok S-K, Min J-K, Lee M-O,

Shin D-Y, Park S-H and Cho M-L (2019) Retinoic Acid Receptor-Related

Receptor Alpha Ameliorates Autoimmune Arthritis via Inhibiting of Th17 Cells and Osteoclastogenesis.

Front. Immunol. 10:2270

doi: 10.3389/fimmu.2019.02270

\section{Retinoic Acid Receptor-Related Receptor Alpha Ameliorates Autoimmune Arthritis via Inhibiting of Th17 Cells and Osteoclastogenesis}

\author{
Jin-Sil Park' ${ }^{1}$, Su-Jin Moon 1,2, Mi-Ae Lim ${ }^{1}$, Jae-Kyeong Byun ${ }^{1}$, Sun-Hee Hwang ${ }^{1}$, \\ SeungCheon Yang ${ }^{1}$, Eun-Kyung Kim ${ }^{1}$, Hohyun Lee ${ }^{3}$, Sung-Min Kim ${ }^{1}$, Jennifer Lee ${ }^{1,2}$, \\ Seung-Ki Kwok ${ }^{1,2}$, Jun-Ki Min ${ }^{1,2}$, Mi-Ock Lee ${ }^{4}$, Dong-Yun Shin ${ }^{3}$, Sung-Hwan Park ${ }^{1,2 * \dagger}$ and \\ Mi-La Cho ${ }^{1,5,6 * t}$ \\ ${ }^{1}$ The Rheumatism Research Center, Catholic Research Institute of Medical Science, College of Medicine, The Catholic \\ University of Korea, Seoul, South Korea, ${ }^{2}$ Division of Rheumatology, Department of Internal Medicine, College of Medicine, \\ Seoul St. Mary's Hospital, The Catholic University of Korea, Seoul, South Korea, ${ }^{3}$ College of Pharmacy, Gachon University, \\ Incheon, South Korea, ${ }^{4}$ College of Pharmacy and Bio-MAX Institute, Research Institute of Pharmaceutical Sciences, Seoul \\ National University, Seoul, South Korea, ${ }^{5}$ Department of Medical Life Science, College of Medicine, The Catholic University of \\ Korea, Seoul, South Korea, ${ }^{6}$ Department of Biomedicine and Health Sciences, College of Medicine, The Catholic University \\ of Korea, Seoul, South Korea
}

Rheumatoid arthritis (RA) is a chronic inflammatory polyarthritis characterized by progressive joint destruction. IL-17-producing CD4 ${ }^{+} \mathrm{T}$ (Th17) cells play pivotal roles in RA development and progression. Retinoic acid receptor-related orphan receptor alpha $(R O R \alpha)$ is a negative regulator of inflammatory responses, whereas ROR $\gamma t$, another member of the ROR family, is a Th17 lineage-specific transcription factor. Here, we investigated the immunoregulatory potential of ROR $\alpha$ in collagen-induced arthritis $(C I A)$ mice, an experimental model of RA. Cholesterol sulfate (CS) or SR1078, a ligand of $\mathrm{ROR} \alpha$, inhibited ROR $\gamma$ t expression and Th17 differentiation in vitro. In addition, fortification of ROR $\alpha$ in T cells inhibited the expression levels of glycolysis-associated genes. We found that $\mathrm{ROR} \alpha$ overexpression in CIA mice attenuated the clinical and histological severities of inflammatory arthritis. The anti-arthritic effect of $R O R \alpha$ was associated with suppressed Th17 differentiation and attenuated mTOR-STAT3 signaling in T cells. Furthermore, altered ROR $\alpha$ activity could directly affect osteoclastogenesis implicated in progressive bone destruction in human RA. Our findings defined a critical role of $R O R \alpha$ in the pathogenesis of RA. These data suggest that ROR $\alpha$ may have novel therapeutic uses in the treatment of RA.

Keywords: rheumatoid arthritis, ROR $\alpha$, IL-17-producing T cells, regulatory T cells, osteoclastogenesis

\section{INTRODUCTION}

Rheumatoid arthritis (RA) is a progressive autoimmune polyarthritis characterized by hyperplastic synovial membrane and subsequent structural damage in affected joints. It leads to significant deterioration of the quality of life of RA patients. Although the pathogenesis of RA is not fully understood, $\mathrm{CD} 4^{+} \mathrm{T}$ cells have been shown to play critical roles in the development and progression of RA. Among the effector T cells, interleukin-17 (IL-17)producing $\mathrm{T}$ (Th17) cells can be distinguished from Th1 or Th2 cells based on their selective 
expression of IL-17A, IL-17F, and IL-21 (1). Th17 cells are involved in the pathogenesis of RA with regard to synovial hypertrophy, enhanced osteoclastogenesis, and neoangiogenesis (2-4). It has been shown that hypoxia-inducible factor (HIF)- $1 \alpha$ is an essential sensor for regulation of Th17 cell differentiation through activation of receptor-related orphan receptor (ROR) $\gamma \mathrm{t}$ and IL-17A, and mTOR is required for HIF- $1 \alpha$ signaling-induced Th17 development $(5,6)$. On the other hand, $\mathrm{CD} 4{ }^{+} \mathrm{CD} 25^{+}$ regulatory $\mathrm{T}$ (Treg) cells are another $\mathrm{T}$ cell subset that mediates immune tolerance and control excessive inflammatory responses (7-9). There is accumulating evidence that the percentage of circulating Treg cells in patients with active RA is reduced compared to that in healthy controls or those with inactive RA (10). The pathophysiological importance of Th17/Treg cell imbalance has attracted interest as a new target in the treatment of RA. The reciprocal regulation of Th17/Treg imbalance can be targeted to satisfy the unmet needs for treatmentresistant RA patients, including patients who are currently using biologics, namely, genetically engineered proteins derived from human genes.

The Retinoic acid receptor-related orphan receptor alpha $(\mathrm{ROR} \alpha)$, also known as nuclear receptor subfamily 1 group $\mathrm{F}$ member 1 , is a member of the steroid/thyroid hormone receptor superfamily of nuclear receptor type transcriptional factors. $\operatorname{ROR} \alpha$ is a potent regulator of a number of genes associated with development of the central nervous system and atherosclerosis $(11,12)$. A natural mutant mouse strain called staggerer $\left(\mathrm{ROR} \alpha^{s g / s g}\right)$ has been shown to have a deletion within the $\mathrm{ROR} \alpha$ gene. $\mathrm{ROR} \alpha^{s g / s g}$ mice have been reported to show tremor, body imbalance, hypo- $\alpha$-lipoproteinemia, and decreased serum cholesterol levels and die within 3-4 weeks after birth (13-15). Recently, $\operatorname{ROR} \alpha$ has been shown to be able to regulate inflammation (16). Lipopolysaccharide-stimulated macrophages from staggerer mice have enhanced susceptibility for the production of tumor necrosis factor-alpha (TNF- $\alpha$ ) and IL- $1 \beta$, suggesting that $\mathrm{ROR} \alpha$ may function as a negative regulator of inflammatory responses $(17,18)$.

ROR $\gamma$ t, another orphan nuclear receptor, has been shown to be selectively expressed in Th17 cells as a Th17-specific transcription factor (19). Interestingly, ROR $\alpha$ is also expressed in Th17 cells and induced by transforming growth factor (TGF)- $\beta$ and IL-6 (20). Overexpression of ROR $\alpha$ can directly promote Th17 differentiation (20). Furthermore, ROR $\alpha$ and ROR $\gamma \mathrm{t}$ can synergistically lead to greater Th17 differentiation and cytokine expression (20). These findings suggest that ROR $\alpha$ may have pathological roles in Th17-induced autoimmune diseases, including RA. However, there is accumulating evidence that $\mathrm{ROR} \alpha$ mediates anti-inflammatory responses in inflammatory diseases, such as sepsis and atherosclerosis $(15,21)$.

Therefore, the present study was performed to determine the effects of $\mathrm{ROR} \alpha$ on the development of autoimmune arthritis using a murine model of RA. To clarify the underlying mechanisms by which $\mathrm{ROR} \alpha$ may exert a therapeutic effect, the changes in Th17 cell and Treg cell development were determined both in vitro and in vivo. Here, we showed that cholesterol sulfate (CS) or SR1078 as a ligand of ROR $\alpha$ could inhibit the number of Th17 cells and IL-17 production by altering transcriptional checkpoints in naïve $\mathrm{T}$ cells. Furthermore, we investigated whether altered $\operatorname{ROR} \alpha$ activity could directly affect osteoclastogenesis implicated in progressive bone destruction in human RA.

\section{MATERIALS AND METHODS}

\section{Animals}

Four- to six-week-old male C57BL/6 and DBA/1J mice were purchased from Orient Bio Inc. (Seongnam, South Korea). Mice harboring a deletion within the $\mathrm{ROR} \alpha$ gene were obtained from the Jackson Laboratory (Bar Harbor, ME). These mice were maintained under specific pathogen-free conditions at the Catholic Research Institute of Medical Science, Catholic University of Korea. Animals were fed standard mouse chow and water ad libitum. All experimental procedures were examined and approved by the Animal Research Ethics Committee of the Catholic University of Korea, and conformed to the National Institutes of Health (USA) guidelines (permit number: 20140126-01, 2017-0139-03).

\section{CIA Induction}

To induce CIA in DBA/1J mice, chicken type II collagen (CII) was dissolved overnight in $0.1 \mathrm{~N}$ acetic acid $(4 \mathrm{mg} / \mathrm{mL})$ with gentle rotation at $4^{\circ} \mathrm{C}$. DBA/1J mice were injected intradermally at the base of the tail with $100 \mu \mathrm{g}$ of CII emulsified in Freund's adjuvant (Chondrex, Redmond, WA). Two weeks later, $100 \mu \mathrm{g}$ of CII dissolved and emulsified at 1:1 with incomplete Freund's adjuvant (Difco, Detroit, MI) was administered to the hind legs of mice as a booster injection. To assess the effects of SR 1078 on the severity of CIA, DBA/1J mice were treated with $10 \mathrm{mg} / \mathrm{kg}$ SR1078 in saline or with vehicle alone via intraperitoneal injections three times per week for 8 weeks on day 7 or 19 after the 1st immunization. For administration of $\operatorname{pcDNA}-\mathrm{ROR} \alpha$, on day 8 after the 1 st immunization, DBA/1J mice were injected intravenously with $100 \mu \mathrm{g}$ of pcDNA-ROR $\alpha$, or with mock vector as a control in $2 \mathrm{~mL}$ of saline within $5 \mathrm{~s}$. Eight days after hydrodynamic intravenous injection, the same mice received intramuscular injection by electroporation of $100 \mu \mathrm{g}$ of $\mathrm{pcDNA}-\mathrm{ROR} \alpha$ or mock vector into the left leg. Intramuscular injection was performed using a 31-gauge needle insulin syringe. Seven days later, mice were injected intramuscularly with $100 \mu \mathrm{g}$ of $\mathrm{pcDNA}-\mathrm{ROR} \alpha$ in the right leg with electroporation $(22,23)$.

\section{Clinical Assessment of Arthritis}

The severity of arthritis was determined by three independent observers. The mice were observed twice a week for the onset and severity of joint inflammation for up to 8 weeks after the primary immunization. The severity of arthritis was assessed on a scale of $0-4$ with the following criteria, as described previously (24): 0 = no edema or swelling; $1=$ slight edema and erythema limited to the foot or ankle; $2=$ slight edema and erythema from the ankle to the tarsal bone; $3=$ moderate edema and erythema from the ankle to the tarsal bone; and $4=$ edema and erythema from the ankle to the entire leg. The arthritis score for each mouse was expressed as the sum of the scores of all four limbs. The highest possible arthritis score for a mouse was therefore 16 . The 
mean arthritis index was used to compare the data among the control and experimental groups.

\section{Histological Evaluation and Immunohistochemistry}

Joint tissues were fixed in $10 \%(\mathrm{v} / \mathrm{v})$ neutral buffered formalin, decalcified in a histological decalcifying agent (Calci-Clear Rapid; National Diagnostics, Atlanta, GA), embedded in paraffin, and cut into sections $5 \mu \mathrm{m}$ thick. The sections were stained with hematoxylin and eosin (H\&E) and Safranin $\mathrm{O}$ to detect proteoglycans. Inflammation was scored using the following criteria: $0=$ no inflammation; $1=$ slight thickening of the lining or infiltration of some cells into the underlying layer; 2 $=$ slight thickening of the lining with infiltration of some cells into the underlying layer; $3=$ thickening of the lining, with an influx of cells into the underlying layer, and cells evident in the synovial space; and $4=$ extensive infiltration of the synovium by inflammatory cells. Cartilage damage was evaluated by staining with Safranin $\mathrm{O}$ and toluidine blue, and the extent of damage was scored using the following criteria: $0=$ no destruction; $1=$ minimal erosion (limited to single spots); $2=$ slight-to-moderate erosion in a limited area; $3=$ more extensive erosion; and $4=$ general destruction. Immunohistochemistry was performed using a Vectastain $\mathrm{ABC}$ kit (Vector Laboratories, Burlingame, CA). Tissues were stained with anti-TNF- $\alpha$, antiIL-1 $\beta$, anti-IL-6, anti-IL-17, and anti-vascular endothelial growth factor (VEGF) antibodies and an isotype control (Santa Cruz Biotechnology, Santa Cruz, CA). Cells were counted visually at higher magnification by projection on a screen and cytokinepositive cells were identified by their brown color.

\section{Confocal Microscopy}

Spleen tissues were snap-frozen in liquid nitrogen and stored at $-70^{\circ} \mathrm{C}$. Spleen tissue sections $(7 \mu \mathrm{m})$ were fixed in acetone and stained for Treg cells using fluorescein isothiocyanate (FITC)labeled anti-Foxp3, phycoerythrin (PE)-labeled anti-CD4 (both from eBioscience, San Diego, CA), and allophycocyanin (APC)labeled anti-CD25 (BioLegend, San Diego, CA) antibodies. To stain Th17 cells, PE-labeled anti-IL-17 (eBioscience), FITC-labeled anti-CD4 (eBioscience), and PE-labeled antiphosphorylated STAT-3 (pTyr705 or pSer727; BD Biosciences) antibodies were used. Tissue and cells were stained at $4^{\circ} \mathrm{C}$ overnight with an antibody against HIF-1 $\alpha$ (Abcam, Cambridge, UK), pmTOR (Cell Signaling Technology, Beverly, MA), and CD4 (BioLegend). LBRM-33 cells were centrifuged onto slides using CytoSpin III (Shandon Scientific, Pittsburgh, PA) at 700 $\mathrm{rpm}$ for $5 \mathrm{~min}$. Cells were air-dried, fixed with methanol, and blocked with $10 \%$ goat serum at room temperature for $30 \mathrm{~min}$. After incubation with appropriate staining antibodies at $4{ }^{\circ} \mathrm{C}$ overnight, sections were analyzed by confocal microscopy (LSM 510 Meta; Carl Zeiss, Oberkochen, Germany). Positive cells were counted visually at higher magnification by four individuals.

\section{Enzyme-Linked Immunosorbent Assay (ELISA)}

The amounts of IL-17 and TNF- $\alpha$ in culture supernatants from mouse or human cells were measured by sandwich ELISA
(R\&D Systems, Minneapolis, MN). Horseradish peroxidaseavidin (R\&D Systems) was used for color development. Blood from the orbital sinus of mice was taken and serum samples were stored at $-20^{\circ} \mathrm{C}$ until use. The levels of immunoglobulin (Ig)G, IgG1, and IgG2a were measured using a mouse ELISA quantification kit (Bethyl Lab Co., Montgomery, TX). The absorbance was determined at a wavelength of $405 \mathrm{~nm}$ on an ELISA microplate reader (Molecular Devices, Sunnyvale, CA).

\section{Isolation of Splenocytes and CD4 ${ }^{+}$T Cells}

Isolation of mouse splenocytes and splenic $\mathrm{CD}^{+}{ }^{+} \mathrm{T}$ cells and differentiation of effector $\mathrm{T}$ cells were performed as described previously (22). To purify splenic $\mathrm{CD} 4^{+} \mathrm{T}$ cells, the splenocytes of mice were incubated with CD4-coated magnetic beads and isolated using magnetic activated cell sorting separation columns (Miltenyi Biotech, Auburn, CA). To establish Th17 cellpolarizing conditions, the sorted $\mathrm{CD} 4^{+} \mathrm{T}$ cells were stimulated with plate-bound anti-CD3 $(0.5 \mu \mathrm{g} / \mathrm{mL})$, anti-CD28 $(1 \mu \mathrm{g} / \mathrm{mL})$, anti-interferon (IFN) $-\gamma(2 \mu \mathrm{g} / \mathrm{mL})$, anti-IL-4 $(2 \mu \mathrm{g} / \mathrm{mL})$, TGF- $\beta$ $(2 \mathrm{ng} / \mathrm{mL})$, and IL-6 $(20 \mathrm{ng} / \mathrm{mL})$ for $72 \mathrm{~h}$. Cells were pretreated with CS (Sigma, St. Louis, MO) for 1 day and then stimulated under the appropriate polarizing conditions.

\section{Flow Cytometry}

Expression levels of cytokines and transcription factors were assessed by intracellular staining using the following antibodies. For intracellular staining: anti-IL-17-FITC, anti-Foxp3-FITC, and anti-Foxp3-PE (all from eBioscience). Cells were stimulated with PMA and ionomycin with the addition of GolgiStop for $4 \mathrm{~h}$. Cultured cells were surface labeled for $30 \mathrm{~min}$ and permeabilized with Cytofix/Cytoperm solution (BD Pharmingen, Heidelberg, Germany). Cells were intracellularly stained with fluorescent antibodies before flow cytometry (FACSCalibur; BD Biosciences, Franklin Lakes, NJ). Events were collected and analyzed with FlowJo software (Tree Star, Ashland, OR).

\section{Western Blotting}

Cells were lysed in Halt protein lysis buffer containing Halt phosphatase inhibitor (Thermo Pierce, Waltham, MA). Lysates were centrifuged at $14,000 \times g$ for $15 \mathrm{~min}$ at $4^{\circ} \mathrm{C}$. Protein concentration was determined by Bradford protein assay (BioRad, Hercules, CA). Proteins were separated by SDS-PAGE and transferred onto Hybond ECL membranes (GE Healthcare, Waukesha, WI) for Western blotting analysis using SNAP i.d. Protein Detection System (Millipore, Billerica, MA). Blots were incubated with antibodies against $\operatorname{ROR} \alpha$ (Santa Cruz) and $\beta$-actin (Sigma). After washing, HRP-conjugated secondary antibodies were added. Hybridized bands were detected using an ECL detection kit (Pierce, Rockford, IL) and Hyperfilm (Agfa, Mortsel, Belgium).

\section{Gene Expression Analysis Using Real-Time Polymerase Chain Reaction}

A LightCycler 2.0 instrument (software version 4.0; Roche Diagnostics, Penzberg, Germany) was used for PCR amplification. All reactions were performed with LightCycler FastStart DNA Master SYBR Green I (Takara, Kyoto, Japan) 
according to the manufacturer's instructions. The following primers were used: $\operatorname{ROR} \alpha, 5^{\prime}$-GGAAGGTCTGCCACGTTA TCTG-3' (sense) and 5'-TCCAAATCCCACCTGGAAAC-3' (antisense); ROR $\gamma \mathrm{T}, \quad 5^{\prime}$-TGTCCTGGGCTACCCTACTG-3' (sense) and 5'-GTGCAGGAGTAGGCCACATT-3' (antisense); IL-17A, 5'-CCTCAAAGCTCAGCGTGTCC-3' (sense) and $5^{\prime}$-GAGCTCACTTTTGCGCCAAG-3' (antisense); Foxp3, $5^{\prime}$-GGCCCTTCTCCAGGACAGA-3' (sense) and $5^{\prime}$-GCT GATCATGGCTGGGTTGT-3' (antisense); STAT3, 5'-CCG TCTGGAAAACTGGATAACTTC-3' (sense) and $5^{\prime}$-CCT TGTAGGACACTTTCTGCTGC-3' (antisense); HIF-1 $\alpha, 5^{\prime}$ AGGCCTAGATGGCTTTGTGA-3' (sense) and $5^{\prime}$-TATCGAG

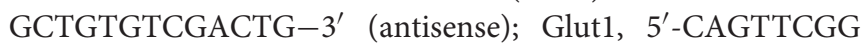
CTATAACACTGGTG-3' (sense) and $5^{\prime}$-GCCCCCGACA GAGAAGATG-3' (antisense); MCT4, 5'-TCACGGGTT TCTCCTACGC-3' (sense) and $5^{\prime}$-GCCAAAGCGGTTCAC ACAC-3' (antisense); HK2, 5'-TGATCGCCTGCTTAT TCACGG-3' (sense) and $5^{\prime}$ - AACCGCCTAGAAATCTC

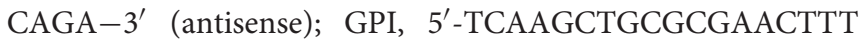
TTG-3' (sense) and 5' - GTTCTTGGAGTAGTCCACCAG-3' (antisense); TPI, 5' -CCAGGAAGTTCTTCGTTGGGG-3' (sense) and 5'-CAAAGTCGATGTAAGCGGTGG-3' (antisense); Eno1, 5'-TGCGTCCACTGGCATCTAC-3' (sense) and $5^{\prime}$-CAGAGCAGGCGCAATAGTTTTA-3' (antisense); PKM, 5'-GCCGCCTGGACATTGACTC-3' (sense) and $5^{\prime}$ CCATGAGAGAAATTCAGCCGAG-3' (antisense); LDH $\alpha$, $5^{\prime}$-CATTGTCAAGTACAGTCCACACT-3' (sense) and $5^{\prime}$ TTCCAATTACTCGGTTTTTGGGA-3' (antisense); TRAP, $5^{\prime}$-TCCTGGCTCAAAAAGCAGTT-3' (sense) and $5^{\prime}$-ACA TAGCCCACACCGTTCTC-3' (antisense); cathepsin $\mathrm{K}, 5^{\prime}$ CAGCAGAGGTGTGTACTATG-3' (sense) and $5^{\prime}$-GCGTTGT TCTTATTCCGAGC-3' (antisense); calcitonin receptor, $5^{\prime}$ CGGACTTTGACACAGCAGAA-3' (sense) and $5^{\prime}$-AGCAG CAATCGACAAGGAGT-3' (antisense); p53, 5'-CACGTAC TCTCCTCCCCTCA-3' (sense) and $5^{\prime}$-CTCCGTCATGTG CTGTGACT-3' (antisense); and $\beta$-actin, $5^{\prime}$-GTACGACCA GAGGCATACAGG-3' (sense) and $5^{\prime}$-GATGACGATATCG CTGCGCTG $-3^{\prime}$ (antisense). The level of mRNA expression was normalized to that of $\beta$-actin mRNA.

\section{In vitro Osteoclastogenesis and Tartrate-Resistant Acid Phosphatase (TRAP) Staining}

Isolation of mouse bone marrow cells, differentiation of osteoclasts, and TRAP staining were performed as described previously (25).

\section{Cell Viability Analysis}

Cell viability was determined using a CCK-8 kit (Dojindo Laboratories, Kumamoto, Japan) according to the manufacturer's instructions. Briefly, splenic CD4 ${ }^{+}$T cells $\left(2 \times 10^{5}\right.$ cells/well, 96well plate) were pre-stimulated with CS for 1 day and cultured with anti-CD3 and anti-CD28 for 3 days. CCK-8 $(10 \mu \mathrm{L})$ was added to each well of the plate. After incubation for $3 \mathrm{~h}$, the absorbance at $450 \mathrm{~nm}$ of each well was measured on a microplate reader.

\section{Statistical Analysis}

Statistical analyses were performed using SAS software (version 9.2; SAS Institute, Cary, NC). Normally distributed continuous data were analyzed using the parametric Student's $t$-test. Non-normally distributed data were analyzed using the nonparametric Mann-Whitney $U$-test. Differences in mean values of various groups were analyzed by analysis of variance (ANOVA) with a post hoc test. Experimental values are presented as means $\pm \mathrm{SD}$. In all analyses, $P<0.05$ (2-tailed) was taken to indicate statistical significance.

\section{RESULTS}

\section{ROR $\alpha$ Is Capable of Suppressing Th17 Cell Differentiation in vitro}

CS is known to induce ROR $\alpha$ transcriptional activity (26-28). To determine whether $\operatorname{ROR} \alpha$ overexpression could regulate the development of Th17 cells, murine T cells were cultured in the presence of CS, a putative natural ligand of $\operatorname{ROR} \alpha$ (29). First, murine splenic $\mathrm{CD} 4^{+} \mathrm{T}$ cells were stimulated with antiCD3 and anti-CD28 antibodies in the presence of CS. CS at concentrations from 0.1 to $40 \mu \mathrm{M}$ showed no cellular toxicity to murine $\mathrm{T}$ cells in culture for $72 \mathrm{~h}$ (Figure 1A). To confirm increased ROR $\alpha$ expression, murine splenic $\mathrm{CD} 4^{+} \mathrm{T}$ cells were pretreated for $24 \mathrm{~h}$ with $\mathrm{CS}$ and then cultured for an additional $24 \mathrm{~h}$ under Th17-polarizing conditions. $\mathrm{ROR} \alpha$ expression was found to be higher following CS treatment compared to that in untreated cells (Figure 1B). Next, we examined the effects of CS on Th17 cell differentiation in vitro. Murine $\mathrm{CD}^{+} \mathrm{T}$ cells were cultured in the presence of anti-CD3, anti-CD28, anti-IFN- $\gamma$, anti-IL-4 antibodies, TGF- $\beta$, and IL-6 with or without CS for $72 \mathrm{~h}$. After stimulation under conditions favoring Th17 cell differentiation, flow cytometry indicated that CSstimulated $\mathrm{T}$ cells were less prone to differentiate toward Th17 cells compared to untreated cells (Figure 1C). The amounts of IL-17A and TNF- $\alpha$ in culture supernatants of CS-treated T cells were significantly $(P<0.05)$ lower than those in culture supernatants of untreated cells (Figure 1D). Next, LBRM-33 murine T lymphoma cells were stimulated with CS for $24 \mathrm{~h}$ and then cultured under Th17-polarizing conditions for an additional $48 \mathrm{~h}$. Overexpression of ROR $\alpha$ by CS resulted in significantly $(P$ $<0.05)$ attenuated IL-17 expression in LBRM-33 cells, whereas Foxp3 expression was reciprocally and significantly $(P<0.05)$ increased (Figures 1E,F). Taken together, these results suggest that inducing $\operatorname{ROR} \alpha$ activity in T cells may represent a novel treatment strategy for management of various Th17-associated diseases, including RA.

\section{Fortification of ROR $\alpha$ Using Various Inducers Inhibits IL-17 Production}

To investigate the mechanisms underlying the inhibition of Th17 differentiation by CS, the expression levels of Th17-related mediators were examined. STAT3 is an essential transcription factor of Th17 cell differentiation through $\operatorname{ROR} \gamma \mathrm{t}$ induction by binding to sites within the first intron of $R O R c$, which encodes ROR $\gamma t(19,30,31)$. As expected, CS treatment induced ROR $\alpha$ 


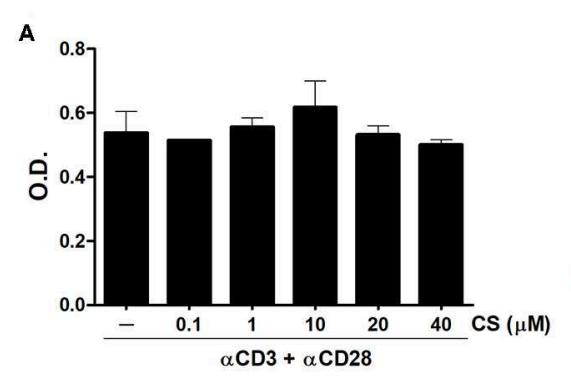

C

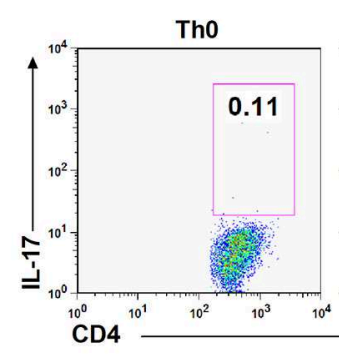

B

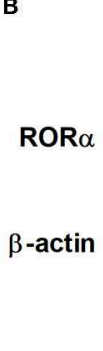

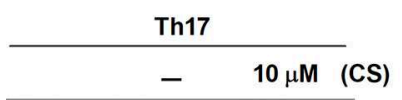

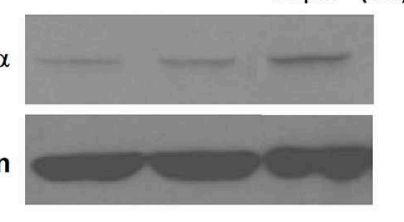

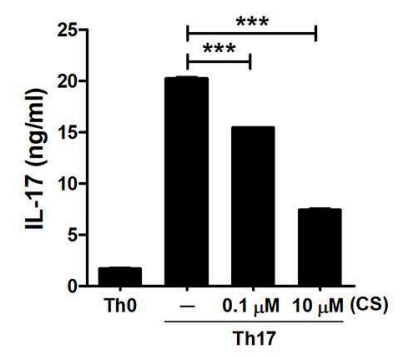

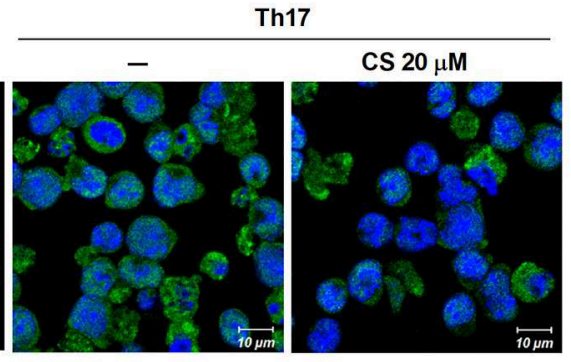

Th17

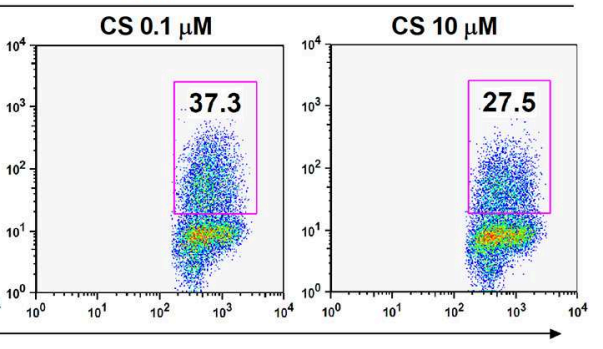

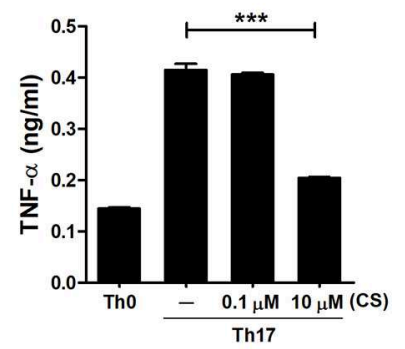

F
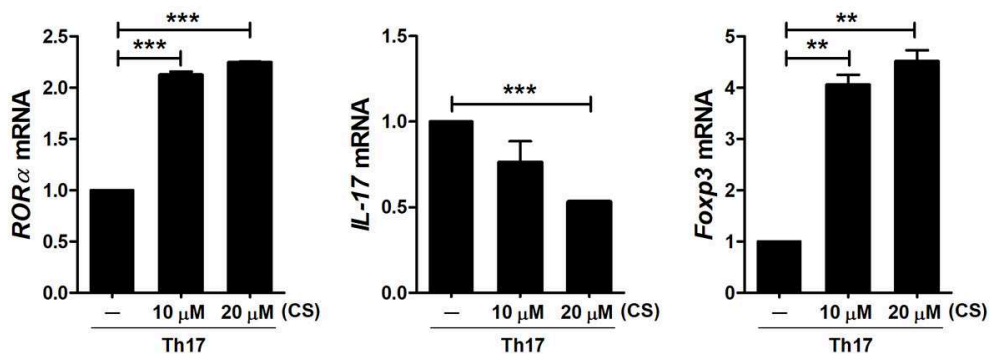

FIGURE 1 | ROR $\alpha$ suppresses Th17 cell differentiation in vitro. (A) Splenic CD4 + T cells from normal 6-week-old C57BL/6 mice were pretreated with CS, a ligand for $\mathrm{ROR} \alpha$, for $24 \mathrm{~h}$ and then stimulated with anti-CD3/anti-CD28 monoclonal antibodies for $72 \mathrm{~h}$. Cell viability was measured using the CCK-8 method. (B) Immunoblotting analysis was performed to determine the expression level of ROR $\alpha$ in CS-treated CD4 ${ }^{+} \mathrm{T}$ cells. Cropped blots are displayed. (C) Murine CD4 ${ }^{+} \mathrm{T}$ cells of C57BL/6 mice were cultured under Th17 cell-polarizing conditions with or without various concentrations of CS for $72 \mathrm{~h}$. These cells were then stained with anti-CD4 and anti-IL-17 antibodies for intracellular flow cytometry analysis. Representative results are shown. (D) Concentrations of IL-17 and TNF- $\alpha$ in culture supernatants of CS-stimulated T cells in (C) were measured by ELISA. (E) CS treatment inhibited IL-17 expression in LBRM-33 cells stimulated under Th17-polarizing conditions. The expression of IL-17 was analyzed by immunostaining and confocal microscopy $(\times 800)$. (F) Expression levels of ROR $\alpha$, IL-17, and Foxp3 in CS-stimulated LBRM-33 cells were determined by real-time polymerase chain reaction. Data are presented as means $\pm \mathrm{SD}$ of two independent experiments. ${ }^{\star \star} P<0.01,{ }^{\star \star \star} P<0.001$.

mRNA expression in murine $\mathrm{T}$ cells but significantly suppressed STAT3, ROR $\gamma$ t, and IL-17 mRNA expression (Figure 2A). Recent studies indicated that HIF- $1 \alpha$ can induce Th17 development through directly activating the transcription of ROR $\gamma \mathrm{t}$ while reciprocally attenuating Treg development by directly targeting Foxp3 $(5,6)$. Our study indicated that overexpression of $\operatorname{ROR} \alpha$ in $\mathrm{T}$ cells suppressed HIF-1 $\alpha$ mRNA expression (Figure 2A). Next, we examined whether changes caused by CS treatment in the process of HIF-1 $\alpha$-dependent glycolytic activity were required for suppressed Th17 cell differentiation. Real-time PCR results indicated that the expression levels of genes encoding glycolysis-associated molecules in CS-stimulated T cells cultured under Th17-skewing conditions were significantly $(P<0.05)$ downregulated compared to those in untreated cells (Figure 2B). To confirm the inhibitory effects of $\operatorname{ROR} \alpha$ on Th17 cell differentiation, murine $\mathrm{T}$ cells were cultured in the presence of anti-CD3, anti-CD28, anti-IFN- $\gamma$, anti-IL-4 antibodies, TGF- $\beta$, and IL-6 with or without SR1078, a selective ROR $\alpha$ ligand, for $72 \mathrm{~h}$ (32). SR1078 treatment significantly suppressed number of Th17 cells and production of IL-17 (Figure 3A). Furthermore, SR1078 treatment increased the expression of $\mathrm{ROR} \alpha$ and p53 mRNA in murine $T$ cells but significantly decreased the expression of ROR $\gamma \mathrm{t}$ mRNA (Figure 3B). To investigate whether chemical inducer of $\operatorname{ROR} \alpha$ has prophylactic activity in the progress of arthritis in vivo, DBA/1J mice were treated with SR1078 via intraperitoneal injections three times per week for 6 weeks on day 7 after the 1 st immunization. SR1078 treatment did not affect body weight changes (Figure 3D), but arthritic severity was controlled from the beginning of arthritis development and intra-articular inflammation and cartilage damage were 
A
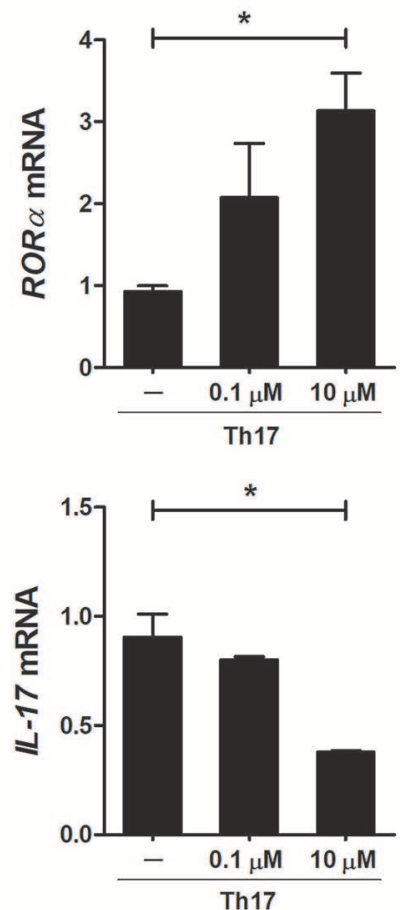
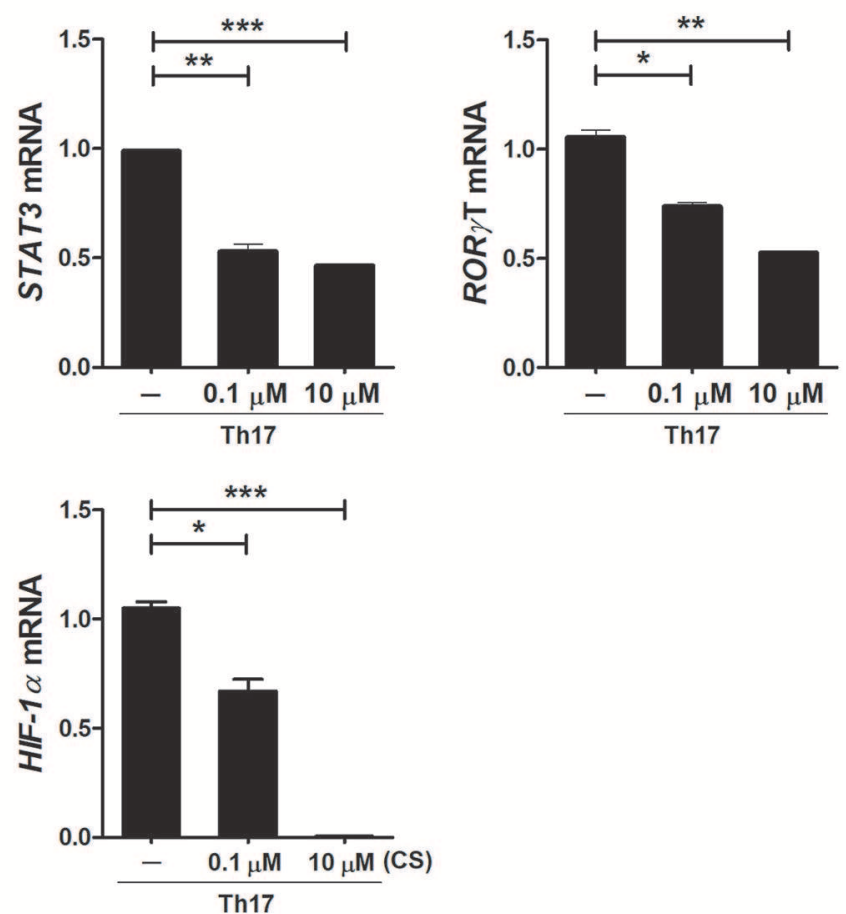

B
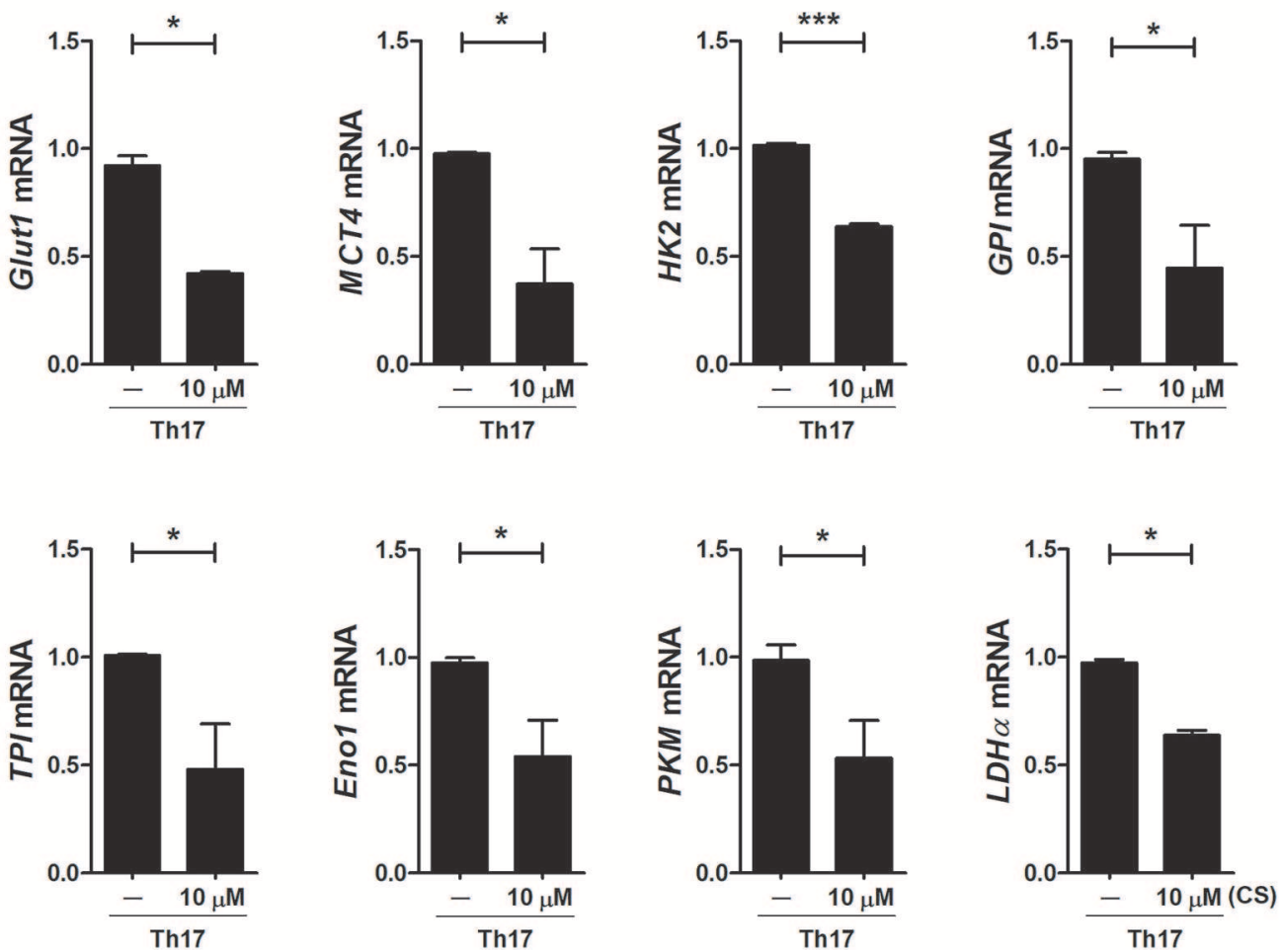

FIGURE 2 | Overexpression of ROR $\alpha$ alters the expression levels of metabolic genes in Th17 cells. (A) CD4 ${ }^{+}$T cells of normal C57BL/6 mice were pretreated with various concentrations of CS and then cultured under Th17-skewing conditions for $72 \mathrm{~h}$. The expression levels of ROR $\alpha, \mathrm{ROR} \gamma \mathrm{t}, \mathrm{STAT} 3$, IL-17, and HIF-1 $\alpha$ in these cells were determined by real-time PCR. (B) CD4 ${ }^{+} \mathrm{T}$ cells of normal C57BL/6 mice were pretreated with various concentrations of CS and then cultured under

Th17-skewing conditions for $72 \mathrm{~h}$. The expression levels of glycolysis-associated molecules were determined by real-time PCR. Data are presented as means \pm SD of two independent experiments. ${ }^{\star} P<0.05,{ }^{\star \star} P<0.01,{ }^{\star \star \star} P<0.001$. 

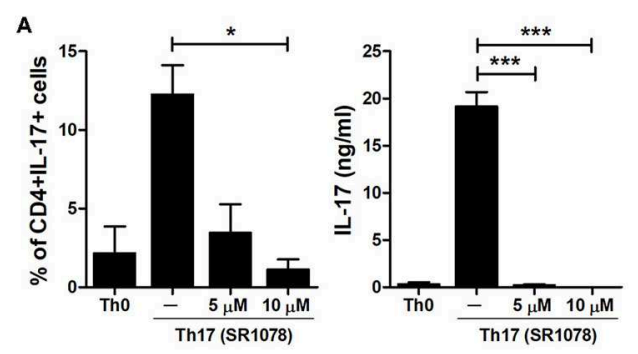

C
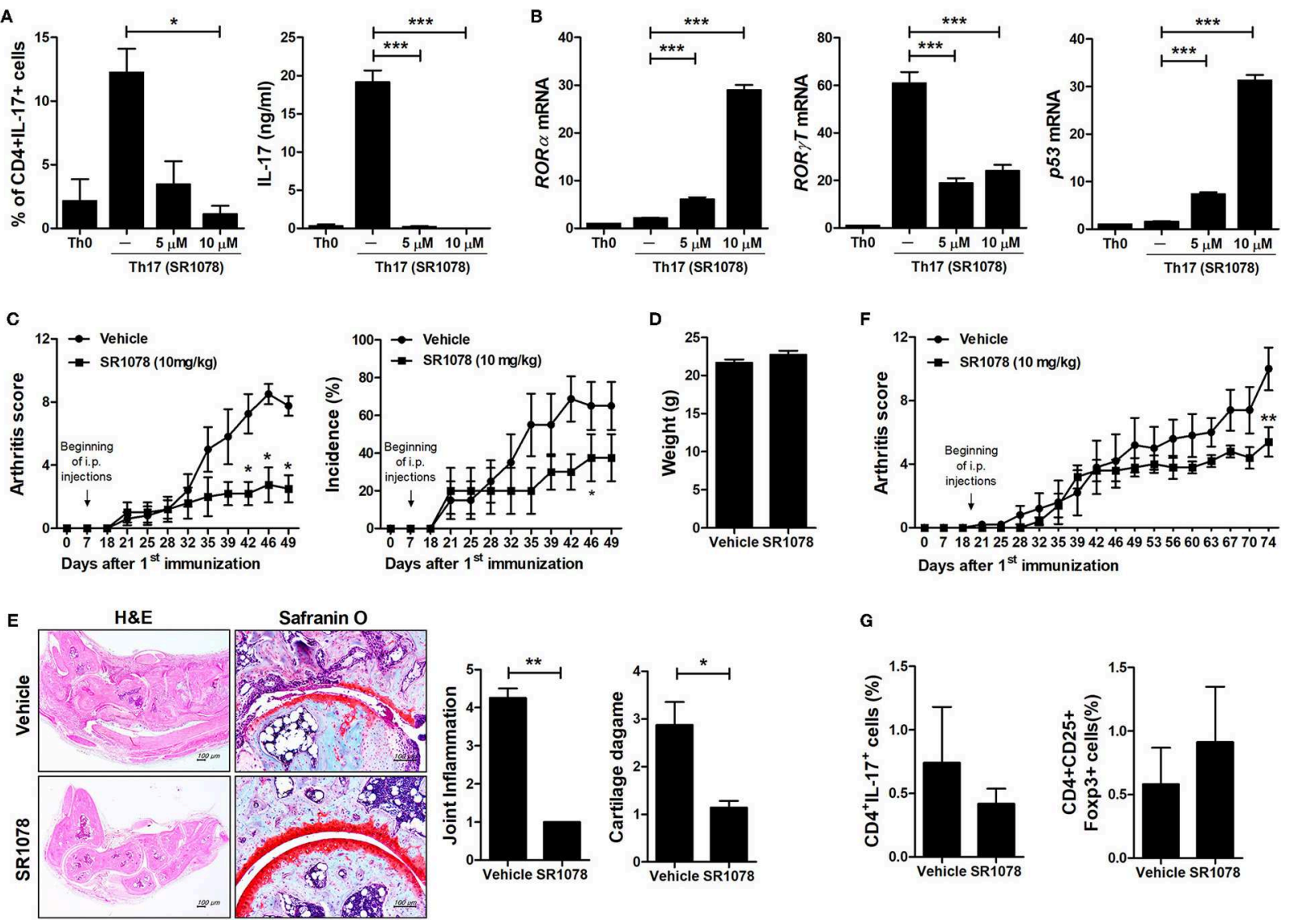

FIGURE 3 | SR1078 inhibits the production of IL-17 and the development of arthritis. (A,B) CD4+ T cells of normal C57BL/6 mice were pretreated with various concentrations of SR1078 and then cultured under Th17-skewing conditions for $72 \mathrm{~h}$. (A) These cells were then stained with anti-CD4 and anti-IL-17 antibodies for intracellular flow cytometry analysis. The level of IL-17 in the culture supernatant was measured by ELISA. (B) The expression levels of ROR $\alpha$, ROR $\gamma t$, and p53 in these cells were determined by real-time PCR. (C-E) At 7 days after 1 st immunization, mice were treated with 10 mg/kg SR1078 in saline or with vehicle alone via intraperitoneal injections three times per week ( $n=4$ /group). Arthritis development was assessed using the arthritis score (left) and incidence (right). (D) The graph shows body weight at 49 days after the first immunization. (E) Sections of articular tissue were prepared from mice treated as described in (C) 49 days after the first immunization and stained with H\&E and safranin O. Representative histological features are shown. The graphs depict the degree of inflammation, bone damage, and cartilage damage. (F,G) At 19 days after the 1st immunization, mice were treated with $10 \mathrm{mg} / \mathrm{kg}$ SR1078 in saline or with vehicle alone via intraperitoneal injections three times per week ( $n=5 /$ group). Clinical score of arthritis is shown for each treatment group over time. (G) At 74 days after the first immunization, the number of CD4 + IL-17 + or CD4 + CD25 + Foxp3 + cells in ex vivo splenocytes was analyzed by flow cytometry. ${ }^{\star} P<0.05$, ${ }^{\star \star} P<0.01,{ }^{\star \star \star} P<0.001$ vs. vehicle-treated mice.

improved compared to the control group (Figures 3C,E). To examine the therapeutic effects of SR1078, SR1078 was injected intraperitoneally in CIA mice at 5 days after second CII immunization. SR1078 treatment in arthritis mice ameliorated the arthritis score (Figure 3F). Although there was no statistical significance, the number of Treg cells increased while the number of Th17 decreased in the SR1078 injection group compared to the control group (Figure 3G). These results suggested that ROR $\alpha$ induced suppression of Th17 cells may be achieved by altering complicated transcriptional checkpoints in naïve $\mathrm{T}$ cells and it could work on the in vivo system.

\section{$\mathrm{ROR} \alpha$ Modulates the Severity of Autoimmune Arthritis}

To further examine whether overexpression of ROR $\alpha$ could modulate the development and severity of arthritis in vivo,
pcDNA-ROR $\alpha$ was administered to CIA mice at 8 days after CII immunization. Our results showed that level of ROR $\alpha$ increased by administration of pcDNA-ROR $\alpha$ (Figures 4B,C) and $\mathrm{ROR} \alpha$ overexpression in arthritis mice reduced the arthritis score and the incidence of arthritis compared to those in mice receiving control pcDNA vector from the early phase of the disease until 90 days after arthritis induction (Figure 4A). On histological examination of the joints, the paws and ankles of CIA mice injected with pcDNA-ROR $\alpha$ exhibited a significantly lower degree of inflammation $(P<0.05)$ and significantly attenuated cartilage damage $(P<0.05)$ compared to those of mice treated with control vector (Figure 4B). In addition, serum levels of IgG, IgG1, and IgG2a in mice injected with pcDNA$\mathrm{ROR} \alpha$ were significantly lower $(P<0.05)$ than those in mice treated with control vector (Figure 4D). IL-17, IL-1 $\beta$, IL-6, and TNF- $\alpha$ are cytokines that have been successfully targeted in the 

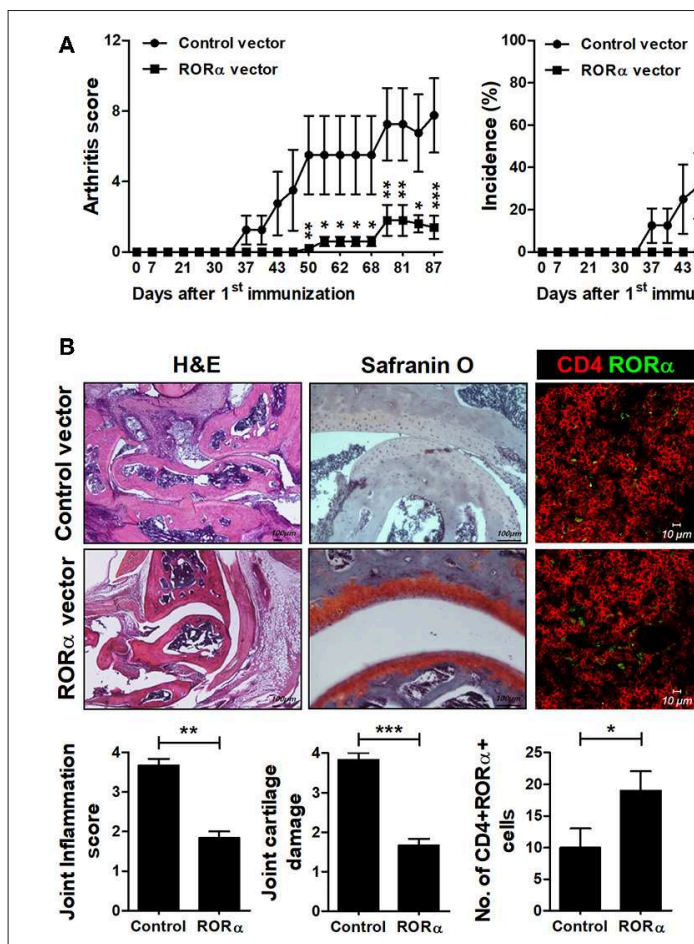

C

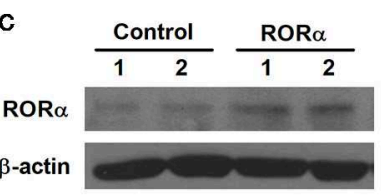

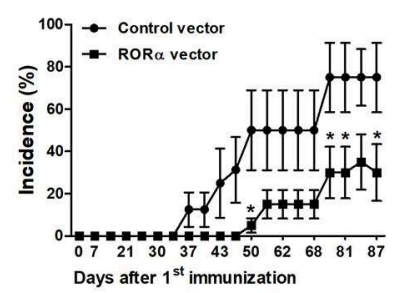

D
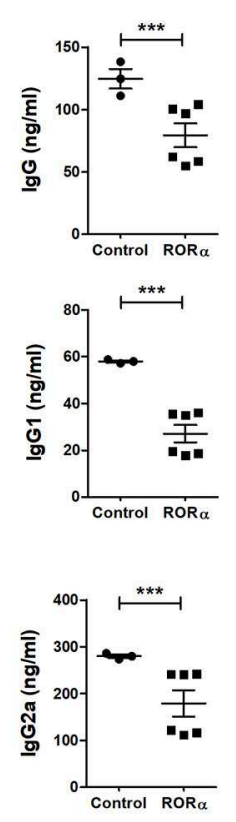

E

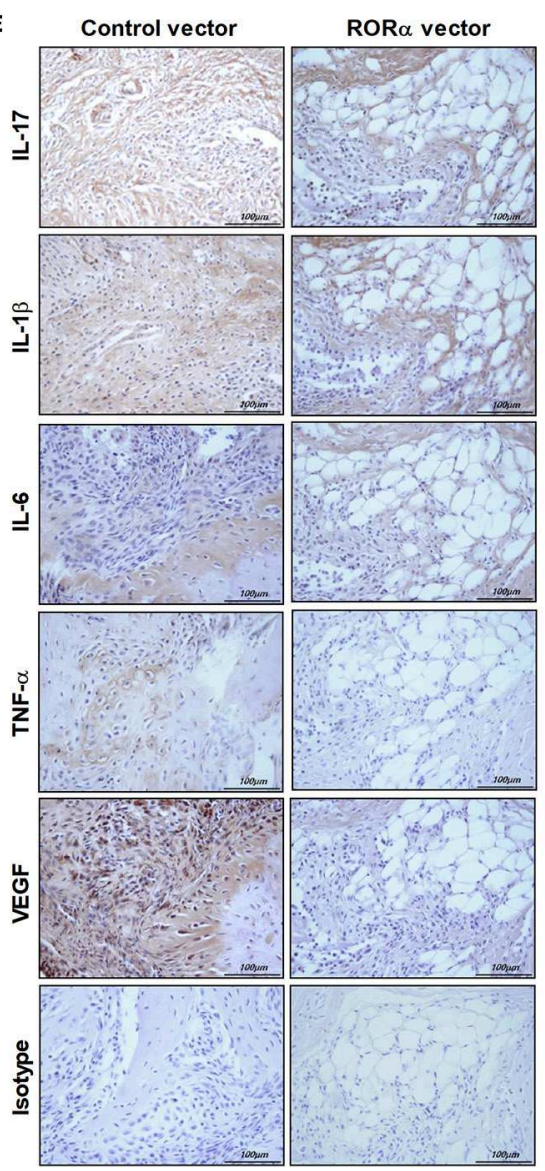

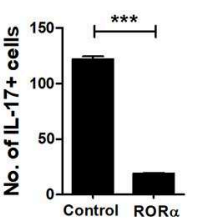
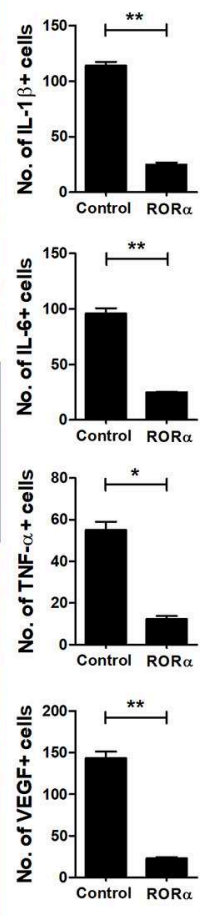

FIGURE 4 | In vivo therapeutic effect of ROR $\alpha$ on the development of autoimmune arthritis. Eight days after immunization with Cll, mice with Cll-induced arthritis (CIA) were injected intravenously with pcDNA-ROR $\alpha$ or pcDNA mock control vector ( $n=6$ or $n=3$ /group, respectively). On days 8 and 15 after hydrodynamic intravenous injection, mice received additional injection of pcDNA-ROR $\alpha$ or pcDNA mock control vector by electroporation into the muscles of both thighs. (A) Clinical scores of arthritis (left) and incidence of arthritis (right) are shown for each treatment group over time (representative results from one of two independent experiments). (B) At 90 days after the first $\mathrm{Cll}$ immunization, tissue sections were obtained from the paw and ankle joints of mice with $\mathrm{CIA}$ and stained with hematoxylin and eosin ( $\mathrm{H} \& \mathrm{E}$; original magnification $\times 40$ ) and Safranin O (original magnification $\times 200$ ) to examine the severity of arthritis. Tissue sections were obtained from spleen of mice with $\mathrm{CIA}$ and immunostained to detect the level of ROR $\alpha$ in $\mathrm{CD} 4+$ cells (left). The histological scores of inflammation, cartilage damage and the number of $\mathrm{CD} 4{ }^{+} \mathrm{ROR} \alpha^{+}$ cells were determined (right). (C) At 90 days after the first Cll immunization, spleens were obtained from spleen of mice treated with pcDNA mock control or pcDNA-ROR $\alpha$ vector and performed western blot to detect the level of ROR $\alpha$. (D) Concentrations of IgG, IgG1, and IgG2a in the sera of mice from each treatment group were measured by ELISA. Data are expressed as dot plots with the mean (bar) for three (pcDNA mock control vector) or six (pcDNA-ROR $\alpha$ ) animals from each group. (E) The expression levels of IL-17, IL-1 $\beta$, IL-6, TNF $\alpha$, and VEGF in the ankle joints were determined by immunohistochemical staining. Bars indicate the means \pm SD of three (pcDNA mock control vector) or six (pcDNA-ROR $\alpha$ ) mice per group. ${ }^{\star} P<0.05,{ }^{\star \star} P<0.01,{ }^{\star \star \star} P<0.001$ vs. pcDNA mock control vector-treated mice.

treatment of RA in numerous clinical trials (33). These cytokines cause synovial inflammation with systemic effects (34). Excessive angiogenesis can maintain chronic inflammation by transporting inflammatory cells and supplying oxygen to inflamed joints (35). Although enhanced angiogenesis is associated with inflammatory conditions, rather than being a disease-specific phenomenon, the targeting of angiogenesis has attracted attention in RA treatment (36-38). Our results indicated that the joints of pcDNA-ROR $\alpha$ treated mice with CIA had markedly lower levels of IL-1 $\beta$, IL-6, TNF- $\alpha$, IL-17, and VEGF expression than those of mice treated with control pcDNA vector (Figure 4E). These results suggest that the overexpression of $\mathrm{ROR} \alpha$ can alleviate the development of inflammatory arthritis in vivo.

\section{Anti-inflammatory Properties of ROR $\alpha$ in Mice With Autoimmune Arthritis Are Associated With Th17 Suppression}

To examine whether $\operatorname{ROR} \alpha$ overexpression could alter the populations of Th17 and Treg cells, IL-17-expressing cells (mainly Th17) and $\mathrm{CD}_{2} 5^{+}$Foxp $3^{+}$cells (mainly Treg) among $\mathrm{CD} 4{ }^{+} \mathrm{T}$ cells in the spleens of arthritic mice were analyzed by confocal microscopy and flow cytometry. Our results revealed that pcDNA-ROR $\alpha$-treated CIA mice had a slight increase in the number of Foxp3-expressing Treg cells with a reciprocal decrease in the number of Th17 cells compared to mice treated with control vector (Figures 5A,B). In addition, the mRNA expression 
A
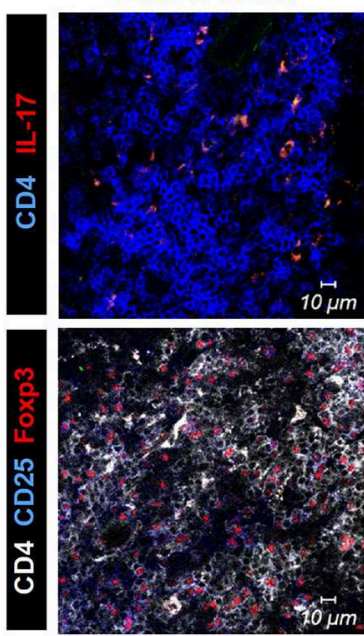

$10 \mu \mathrm{m}$

B

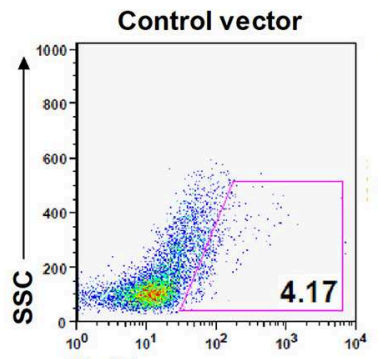
IL-17

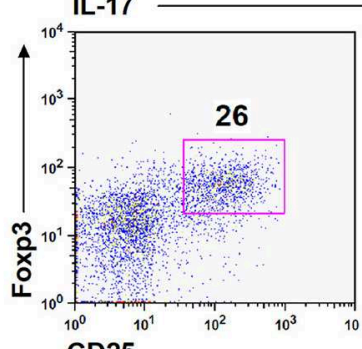

CD25

\section{ROR $\alpha$ vector}
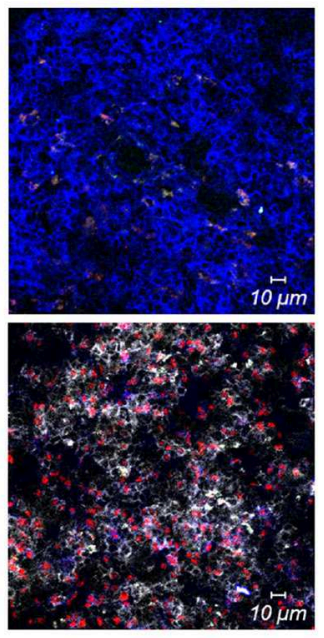
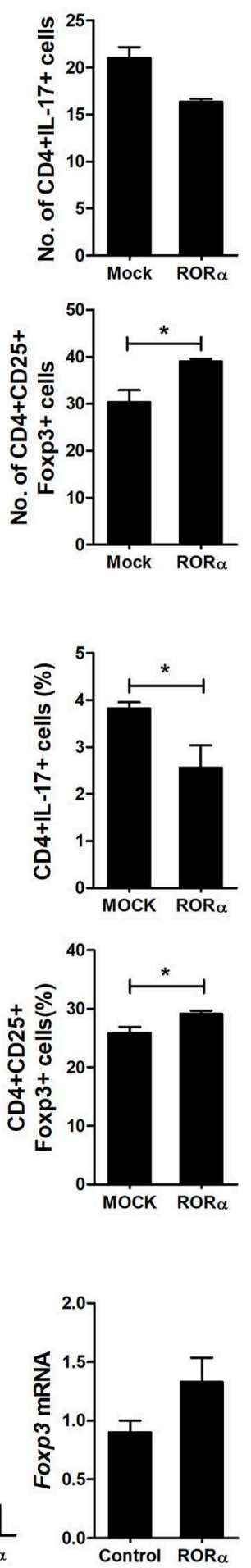

FIGURE 5 | Reciprocal effects of ROR $\alpha$ treatment on differentiation of Th17 and Treg cells in vivo. At 90 days after the first Cll immunization, spleens were obtained from pcDNA-ROR $\alpha$ - or pcDNA mock control vector-treated CIA mice. (A) Spleens were examined by immunofluorescence staining with monoclonal antibodies against CD4, IL-17, CD25, and Foxp3. Original magnification $\times 400$. Right, CD4(blue $)^{+} \mathrm{IL}-17$ (red) ${ }^{+}$Th17 cells and CD4(white) ${ }^{+} \mathrm{CD} 25(\mathrm{blue})^{+}$Foxp3(red) ${ }^{+}$Treg cells were counted visually at higher magnification by projection onto a screen (with each confocal image representative of four fields of view). Results are presented as means \pm SD for the number of positive cells in three mice per group. (B) The proportions of IL-17 ${ }^{+}$or $\mathrm{CD}_{25} 5^{+}$Foxp3 ${ }^{+}$cells among splenic CD4 ${ }^{+} \mathrm{T}$ cells in each group of mice were assessed by flow cytometry. Representative flow cytometry plots from one of two independent experiments are shown (left). Results are presented as means \pm SD for three mice per group (right). (C) Expression levels of ROR $\alpha, R O R \gamma t$, IL-17, and Foxp3 of isolated splenocytes described in (B) were determined by real-time PCR. Bars show the means \pm SD results in three mice per group from at least three independent experiments. ${ }^{\star} P<0.05$, ${ }^{\star \star \star} P<0.001$ vs. mock control vector-treated mice. 
levels of ROR $\alpha$ and Foxp3 were increased, whereas those of ROR $\gamma \mathrm{t}$ and IL-17 were decreased in splenocytes isolated from pcDNA-ROR $\alpha$-treated CIA mice compared to those isolated from CIA mice treated with mock vector (Figure 5C). The numbers of pSTAT3 (Y705 and S727)-expressing CD4 ${ }^{+} \mathrm{T}$ cells in the spleens of pcDNA-ROR $\alpha$-treated CIA mice were significantly $(P<0.05)$ decreased compared to those in the spleens of CIA mice treated with mock vector (Figure 6A). Confocal microscopy also revealed that the proportions of HIF- $1 \alpha$-expressing CD $4^{+} \mathrm{T}$ cells were significantly decreased in pcDNA-ROR $\alpha$-treated CIA mice (Figure 6B). As mTOR is required for HIF- $1 \alpha$ signalinginduced Th17 development and diminished Treg differentiation (6), we examined whether the reciprocal regulation of Th17/Treg cells in pcDNA-ROR $\alpha$-treated arthritic mice was dependent on reduced HIF-1 $\alpha$ signaling. As expected, the number of pmTORexpressing $\mathrm{CD}^{+}{ }^{+}$splenic $\mathrm{T}$ cells was decreased in CIA mice
A

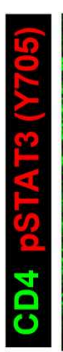

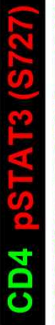
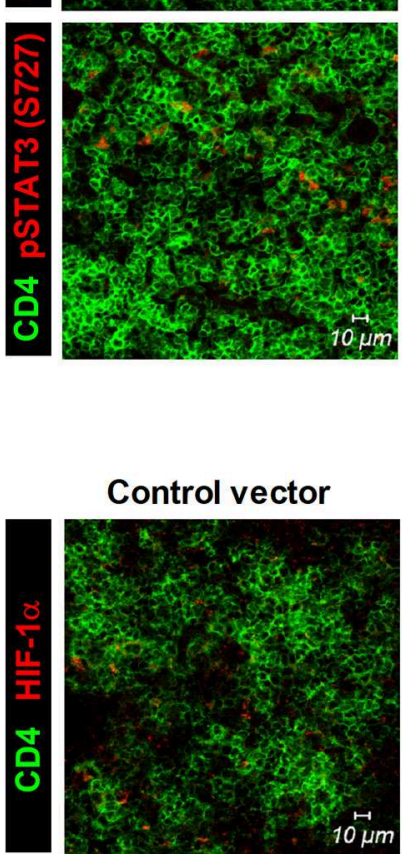

\begin{tabular}{l}
$\frac{1}{6}$ \\
$\frac{1}{2}$ \\
$\frac{1}{0}$ \\
\hline
\end{tabular}

Control vector

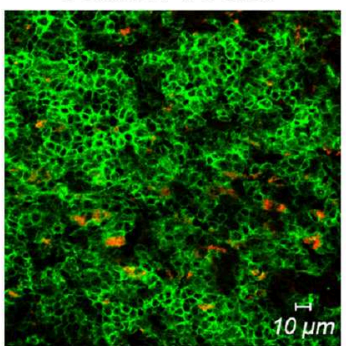

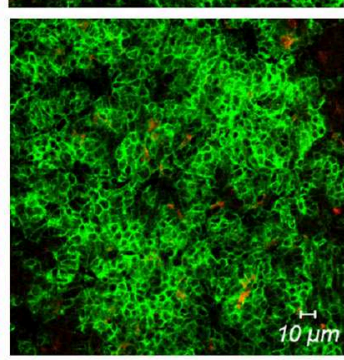
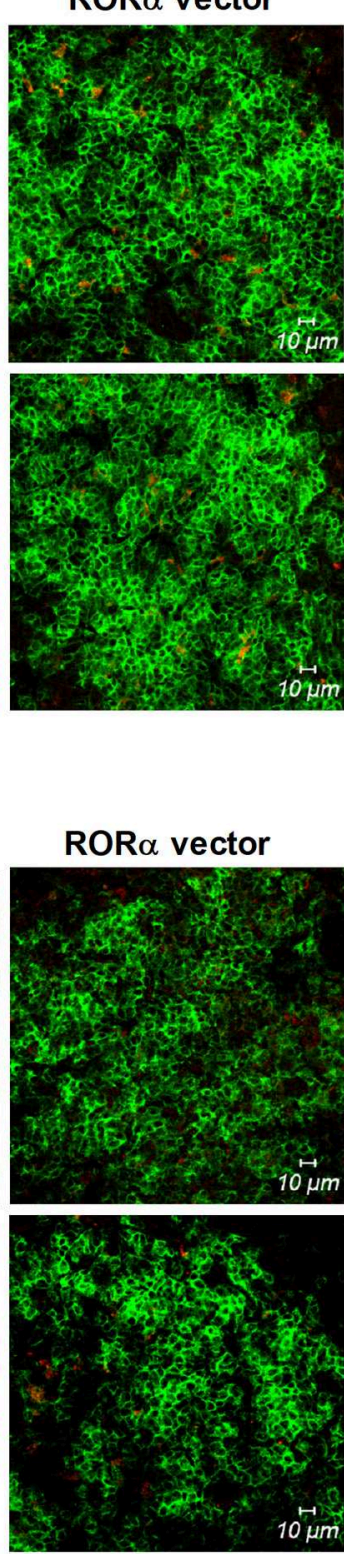
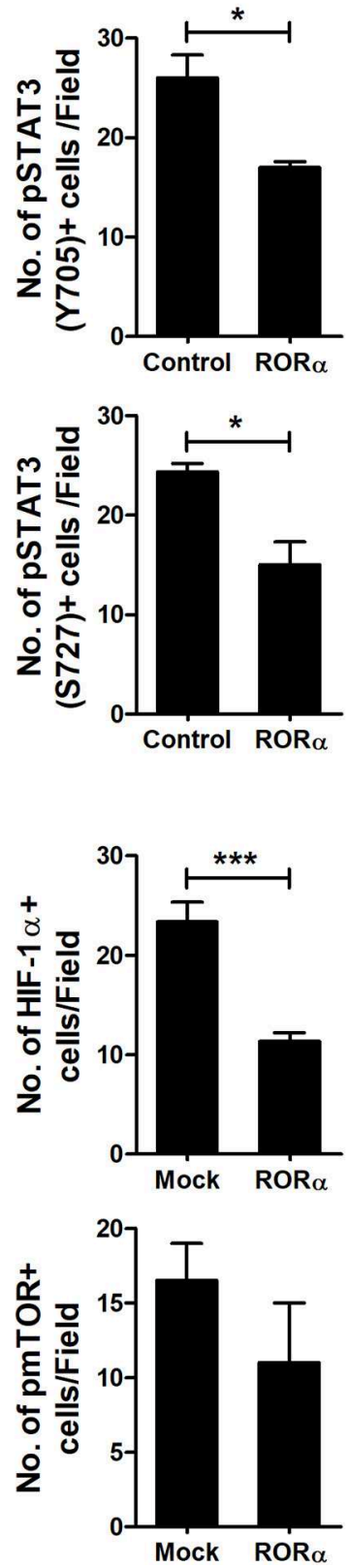

FIGURE 6 | ROR $\alpha$ modulates mTOR-STAT3 signaling pathway. At 90 days after the first CII immunization, spleens were isolated from pcDNA-ROR $\alpha$ - or pcDNA mock control vector-treated CIA mice and subjected to immunofluorescence staining with monoclonal antibodies against CD4 (green), pSTAT3 (Tyr705; red), pSTAT3 (Ser727; red) (A), HIF-1 $\alpha$ (red), or phosphorylated mTOR (red) (B). Cells were counted visually at higher magnification by projection onto a screen. Results are presented as means $\pm \mathrm{SD}$ of three mice per group (right bar graph). ${ }^{\star} P<0.05$, ${ }^{\star \star \star} P<0.001$ vs. pcDNA mock control vector-treated mice. 
injected with pcDNA-ROR $\alpha$ along with reduced expression of HIF-1 $\alpha$ (Figure 6B). These results suggest that overexpression of $\operatorname{ROR} \alpha$ in mice with autoimmune arthritis exerts antiinflammatory effects associated with reciprocal regulation of Th17/Treg cell populations in vivo.

\section{Inhibition of Osteoclastogenesis by ROR $\alpha$}

RA is a prototypical inflammatory arthritis characterized by devastating inflammation-driven cartilage and bone destruction. Joint destruction in RA is mainly attributable to abnormal activation of osteoclasts responsible for bone resorption regulated by macrophage colony-stimulating factor (M-CSF) and receptor activator of NFKB ligand (RANKL) $(39,40)$. Previous reports have shown that mutant mouse staggerer $(\mathrm{sg} / \mathrm{sg})$ carrying a deletion within the ROR $\alpha$ gene is osteopenic with thin long bones compared to wild-type mice (41). To examine the effects of ROR $\alpha$ on in vitro osteoclastogenesis, bone marrow-derived monocyte/macrophage (BMM) cells isolated from pcDNA-ROR $\alpha$ or control pcDNA vector-injected CIA mice were stimulated with M-CSF alone or together with RANKL. Based on TRAP staining, our results indicated that overexpression of ROR $\alpha$ in arthritic mice significantly $(P<0.05)$ reduced osteoclast differentiation (Figure 7A). To investigate the direct effects of ROR $\alpha$ activity on in vitro osteoclastogenesis, BMM cells were cultured with M-CSF and RANKL in the presence or absence of CS. CS treatment in murine BMM cells effectively inhibited the differentiation of osteoclasts in a dosedependent manner (Figure 7B). To characterize the molecular mechanisms involved in the attenuation of osteoclastogenesis in CS-treated BMM cells, mRNA levels of various osteoclastogenic markers, such as TRAP, cathepsin $\mathrm{K}$, and calcitonin receptor, were measured by real-time PCR. The mRNA expression levels of all of these osteoclastogenic markers were decreased by CS in a dose-dependent manner (Figure 7C). These results suggested that ROR $\alpha$ may have novel therapeutic uses for inhibition of the progression of joint destruction in RA patients, which is mainly caused by activated osteoclasts.

\section{DISCUSSION}

In this study, we investigated whether ROR $\alpha$ activity could modulate inflammatory responses in a murine model of RA. Our results indicated that overexpression of $\mathrm{ROR} \alpha$ in vivo significantly reduced the clinical and histological severities of autoimmune arthritis. Enhanced ROR $\alpha$ activity exerted its anti-inflammatory effects by suppressing the differentiation of Th17 cells. Interestingly, CS-induced suppression of Th17 cell differentiation was associated with inhibition of HIF- $1 \alpha$ and decreased expression of glycolysis-associated molecules. It is increasingly evident that metabolic reprogramming has a potential role in the control of cellular differentiation, activation, and function. However, the fundamental mechanisms that mediate such processes remain to be elucidated. Our results suggest that enhancing ROR $\alpha$ activity in $\mathrm{T}$ cells under an inflammatory milieu where naïve $\mathrm{CD} 4^{+} \mathrm{T}$ cells can be differentiated into Th17 cells may be useful as a novel treatment strategy for Th17-associated diseases, such as RA.
Retinoic-related orphan receptors $\operatorname{ROR} \alpha, \beta$, and $\gamma$ constitute a subfamily of nuclear receptors that can regulate gene transcription by binding to ROR-response elements in the promoters of target genes as a monomer $(12,42,43)$. ROR $\alpha$ as a constitutive activator of transcription can modulate a wide spectrum of genes expressed in various organs, including the brain, skeletal muscle, kidney, and hair follicles (42, 44). It has been reported that $\operatorname{ROR} \alpha$ can regulate normal physiological functions, such as lipid and steroid metabolism (12). An important aspect of $\operatorname{ROR} \alpha$ is that it has an antiinflammatory role via inhibition of NF-KB $(16-18,45,46)$. It was reported that ROR $\alpha 1$ inhibits the expression of TNF$\alpha$-induced IL-6 and IL-8 via increasing IкB $\alpha$ in vascular smooth muscle cells and ROR $\alpha 1$ and ROR $\alpha 4$ reduces TNF$\alpha$-induced translocation of p50 and to the nucleus $(16,45)$. Furthermore, ROR $\alpha$ significantly repressed the production of TNF- $\alpha$ in Kupffer cells (46). TNF- $\alpha$-producing T cells are also known to play important pathogenic roles, but the effects of ROR $\alpha$ on these T cells have not been elucidated yet. In this study, we identified that ROR $\alpha$ could control the production of TNF- $\alpha$ in Th17 cells. A recent study indicated that ROR $\alpha$ is a positive regulator of tumor suppressor p53, leading to increases in its transcriptional activity and protein stability (47). Interestingly, we found recently that p53 can alleviate autoimmune arthritis by regulating the balance between Th17 and Treg subsets through direct binding to STAT3 and STAT5 (22). Taken together, these observations suggest that ROR $\alpha$ has anti-inflammatory functions in autoimmune diseases, such as RA.

ROR $\gamma \mathrm{t}$, a member of the retinoic acid receptor-related orphan nuclear hormone receptor family, is expressed specifically under Th17 differentiation conditions (19). ROR $\gamma \mathrm{t}$ is a master transcription factor that drives Th17 cell lineage generation (19). Both ROR $\gamma t$ and $R O R \alpha$ are members of the retinoic acid receptor-related orphan nuclear hormone receptor family (48). Yang et al. demonstrated that $\operatorname{ROR} \alpha$ is also expressed by Th17 cells and that ROR $\alpha$ overexpression can promote Th17 differentiation (20). They also reported that ROR $\alpha$ and ROR $\gamma$ t can synergistically lead to Th17 generation, suggesting that ROR $\alpha$ plays a pivotal role in Th17 differentiation as another Th17 lineage-specific transcription factor. The present study indicated that ROR $\alpha$ has anti-inflammatory effects and potentially antagonistic properties during Th17 differentiation. In addition, we found that overexpression of $\mathrm{ROR} \alpha$ activity in arthritic mice attenuated the expression of ROR $\gamma t$ and IL17. Cellular responses to any stimulus are context-dependent. We focused on the biological roles of ROR $\alpha$ in autoimmune arthritis, which may explain, at least in part, the discrepancies between our results and those of Yang et al. in multiple sclerosis model (20). Multiple sclerosis is a disease in which T cells are primarily initiators and mediators whereas RA is a disease caused by the interaction of fibroblast-like synoviocytes with innate immune cells and adaptive immune cells. It was reported that ROR $\alpha$ is capable of negative regulation in various cells including macrophages $(18,49)$. Furthermore, recently, it was reported that vitamin A can induce changes in gut microbiota composition and thereby increase the expression of CD38 and ROR $\alpha$ (50). 


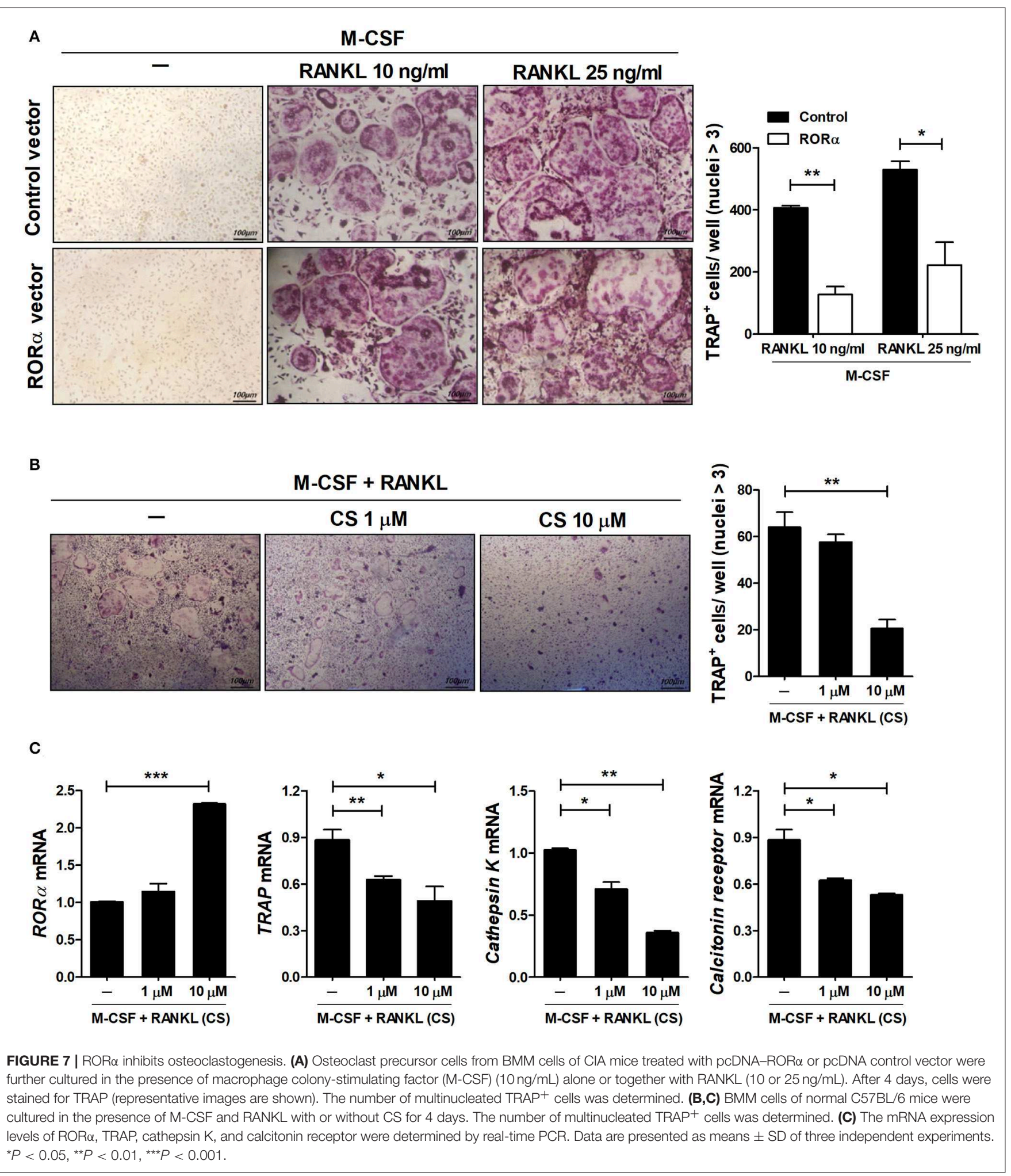

Considering these various possibilities, further studies are needed on the effect of ROR $\alpha$ on $\mathrm{T}$ cells and other immune cells in RA.
Biologically, it is puzzling that another molecule, $\operatorname{ROR} \alpha$, and ROR $\gamma$ t have the same role in Th17 cells. Interestingly, Farez et al. recently reported that $\mathrm{ROR} \alpha$ activity can promote the generation 
of $\mathrm{CD}^{+}$IL-10-producing type 1 regulatory $\mathrm{T}$ cells in an animal model of experimental autoimmune encephalomyelitis, indicating the immunoregulatory potential of $\operatorname{ROR} \alpha$ (51). The regulation of effector $\mathrm{T}$ and Treg cells has been acknowledged mainly in the interaction with transcription factors. However, accumulating evidence suggests that changes in basic cellular metabolism also have an influence on $\mathrm{T}$ cell proliferation and cell fate. Activated $\mathrm{T}$ cells have to adjust their metabolic programs to satisfy the metabolic demands of biosynthetic precursors to have sufficient energy to participate in immune response (5255). For example, activated $\mathrm{CD}^{+}{ }^{+} \mathrm{T}$ cells are highly anabolic. They can increase glycolysis and increase glucose uptake to generate ATP and fundamental sources. In contrast, Tregs utilize lipid oxidation as a primary metabolic pathway to expand and function even in the absence of glucose $(6,56)$. Consistent with these findings, the results of the present study indicated that alterations of the glycolytic pathway following increased $\mathrm{ROR} \alpha$ activity may underlie the tendency toward Treg cell differentiation from naïve $\mathrm{T}$ cells rather than toward Th17 cells.

It is noteworthy that $\operatorname{ROR} \alpha$ appeared to regulate the differentiation of osteoclasts in RA. Bone tissue is a highly metabolically active and organized tissue, which is continuously remodeled to repair damage and maintain the balance through the concerted actions of bone cells, including bone resorption by osteoclasts and bone formation by osteoblasts. ROR $\alpha$ has been implicated in the regulation of bone biology. $\mathrm{ROR} \alpha$ homozygous mutant mice have long thin bones and diminished total bone mineral content in the tibia compared to heterozygotes or wildtype mice (41). These observations suggest that ROR $\alpha$ activity is related to osteoclastogenesis. Further studies are needed to understand the relationship between ROR $\alpha$ and bone biology.

In conclusion, CS, a putative natural ligand of $\operatorname{ROR} \alpha$, and SR1078, a selective ROR $\alpha$ ligand, inhibited number of Th17 cells and IL-17 production. Fortification of ROR $\alpha$-mediated Th17 inhibition was associated with attenuated gene expression levels of glycolysis-associated molecules as well as p53. Overexpression of $\operatorname{ROR} \alpha$ reduced the clinical severity of arthritis and the extent of histological inflammation in a murine model of RA. In addition, $\mathrm{ROR} \alpha$ overexpression in vivo significantly attenuated the expression of proinflammatory cytokines, such

\section{REFERENCES}

1. Weaver CT, Harrington LE, Mangan PR, Gavrieli M, Murphy KM. Th17: an effector CD4 T cell lineage with regulatory T cell ties. Immunity. (2006) 24:677-88. doi: 10.1016/j.immuni.2006.06.002

2. Koenders MI, Kolls JK, Oppers-Walgreen B, van den Bersselaar L, Joosten LA, Schurr JR, et al. Interleukin-17 receptor deficiency results in impaired synovial expression of interleukin-1 and matrix metalloproteinases 3, 9, and 13 and prevents cartilage destruction during chronic reactivated streptococcal cell wall-induced arthritis. Arthritis Rheum. (2005) 52:323947. doi: 10.1002/art.21342

3. Kim KW, Kim HR, Kim BM, Cho ML, Lee SH. Th17 cytokines regulate osteoclastogenesis in rheumatoid arthritis. Am J Pathol. (2015) 185:301124. doi: 10.1016/j.ajpath.2015.07.017

4. Kim SJ, Chen Z, Chamberlain ND, Volin MV, Swedler W, Volkov $\mathrm{S}$, et al. Angiogenesis in rheumatoid arthritis is fostered directly as IL-17, IL-1 $\beta$, IL-6, TNF- $\alpha$, and VEGF. Furthermore, ROR $\alpha$ activity inhibited osteoclastogenesis. These findings suggest that ROR $\alpha$ may be a novel therapeutic target for RA management through inhibition of Th17 production and prevention of bone destruction.

\section{DATA AVAILABILITY STATEMENT}

All datasets generated for this study are included in the manuscript/supplementary files.

\section{ETHICS STATEMENT}

All experimental procedures were examined and approved by the Animal Research Ethics Committee of the Catholic University of Korea, and conformed to the National Institutes of Health (USA) guidelines (permit number: 2014-0126-01, 2017-0139-03).

\section{AUTHOR CONTRIBUTIONS}

J-SP, S-JM, J-KM, S-HP, and M-LC: study design. J-SP, M-AL, J-KB, S-HH, SY, E-KK, HL, and S-MK: data acquisition. J-SP, S-JM, JL, S-KK, J-KM, M-OL, D-YS, S-HP, and M-LC: data analysis and interpretation. J-SP, S-JM, S-HP, and M-LC: manuscript drafting. All authors have critically reviewed the manuscript and approved the final manuscript.

\section{FUNDING}

This study was supported by a grant of the Korean Health Technology R\&D Project, Ministry for Health \& Welfare, Republic of Korea (HI14C1894), by Basic Science Research Program through the National Research Foundation of Korea (NRF) funded by the Ministry of Education (Grant No. NRF2018R1D1A1B07048554), by the Bio \& Medical Technology Development Program of the National Research Foundation (NRF) \& funded by the Korean government (MSIT) (No. NRF2017M3A9F3041045) and by the National Research Foundation of Korea (NRF) grant funded by the Korea government (MSIP) (NRF-2017R1A2B3007688). by toll-like receptor 5 ligation and indirectly through interleukin17 induction. Arthritis Rheum. (2013) 65:2024-36. doi: 10.1002/art. 37992

5. Dang EV, Barbi J, Yang HY, Jinasena D, Yu H, Zheng Y, et al. Control of $\mathrm{T}(\mathrm{H}) 17 / \mathrm{T}$ (reg) balance by hypoxia-inducible factor 1. Cell. (2011) 146:77284. doi: 10.1016/j.cell.2011.07.033

6. Shi LZ, Wang R, Huang G, Vogel P, Neale G, Green DR, et al. HIF1 $\alpha$ dependent glycolytic pathway orchestrates a metabolic checkpoint for the differentiation of TH17 and Treg cells. J Exp Med. (2011) 208:136776. doi: $10.1084 /$ jem. 20110278

7. Bettelli E, Carrier Y, Gao W, Korn T, Strom TB, Oukka M, et al. Reciprocal developmental pathways for the generation of pathogenic effector TH17 and regulatory T cells. Nature. (2006) 441:235-8. doi: 10.1038/nature 04753

8. Miossec P. Diseases that may benefit from manipulating the Th17 pathway. Eur J Immunol. (2009) 39:667-9. doi: 10.1002/eji.200839088 
9. Zhu J, Yamane H, Paul WE. Differentiation of effector CD4 T cell populations (*). Annu Rev Immunol. (2010) 28:44589. doi: 10.1146/annurev-immunol-030409-101212

10. Sempere-Ortells JM, Perez-Garcia V, Marin-Alberca G, Peris-Pertusa A, Benito JM, Marco FM, et al. Quantification and phenotype of regulatory T cells in rheumatoid arthritis according to disease activity score-28. Autoimmunity. (2009) 42:636-45. doi: 10.3109/08916930903061491

11. Hamilton BA, Frankel WN, Kerrebrock AW, Hawkins TL, FitzHugh W, Kusumi K, et al. Disruption of the nuclear hormone receptor RORalpha in staggerer mice. Nature. (1996) 379:736-9. doi: 10.1038/379736a0

12. Jetten AM. Retinoid-related orphan receptors (RORs): critical roles in development, immunity, circadian rhythm, and cellular metabolism. Nucl Recept Signal. (2009) 7:e003. doi: 10.1621/nrs.07003

13. Steinmayr M, Andre E, Conquet F, Rondi-Reig L, Delhaye-Bouchaud $\mathrm{N}$, Auclair N, et al. staggerer phenotype in retinoid-related orphan receptor alpha-deficient mice. Proc Natl Acad Sci USA. (1998) 95:39605. doi: 10.1073/pnas.95.7.3960

14. Dussault I, Fawcett D, Matthyssen A, Bader JA, Giguere V. Orphan nuclear receptor ROR alpha-deficient mice display the cerebellar defects of staggerer. Mech Dev. (1998) 70:147-53. doi: 10.1016/S0925-4773(97)00187-1

15. Mamontova A, Seguret-Mace S, Esposito B, Chaniale C, Bouly M, DelhayeBouchaud N, et al. Severe atherosclerosis and hypoalphalipoproteinemia in the staggerer mouse, a mutant of the nuclear receptor RORalpha. Circulation. (1998) 98:2738-43. doi: 10.1161/01.CIR.98.24.2738

16. Delerive P, Monte D, Dubois G, Trottein F, Fruchart-Najib J, Mariani J, et al. The orphan nuclear receptor ROR alpha is a negative regulator of the inflammatory response. EMBO Rep. (2001) 2:42-8. doi: 10.1093/embo-reports/kve007

17. Kopmels B, Mariani J, Delhaye-Bouchaud N, Audibert F, Fradelizi D, Wollman EE. Evidence for a hyperexcitability state of staggerer mutant mice macrophages. J Neurochem. (1992) 58:192-9. doi: 10.1111/j.1471-4159.1992.tb09295.x

18. Stapleton CM, Jaradat M, Dixon D, Kang HS, Kim SC, Liao G, et al. Enhanced susceptibility of staggerer (RORalphasg/sg) mice to lipopolysaccharideinduced lung inflammation. Am J Physiol Lung Cell Mol Physiol. (2005) 289:L144-52. doi: 10.1152/ajplung.00348.2004

19. Ivanov II, McKenzie BS, Zhou L, Tadokoro CE, Lepelley A, Lafaille JJ, et al. The orphan nuclear receptor RORgammat directs the differentiation program of proinflammatory IL-17+ T helper cells. Cell. (2006) 126:112133. doi: 10.1016/j.cell.2006.07.035

20. Yang XO, Pappu BP, Nurieva R, Akimzhanov A, Kang HS, Chung Y, et al. $\mathrm{T}$ helper 17 lineage differentiation is programmed by orphan nuclear receptors ROR alpha and ROR gamma. Immunity. (2008) 28:2939. doi: 10.1016/j.immuni.2007.11.016

21. Garcia JA, Volt H, Venegas C, Doerrier C, Escames G, Lopez LC, et al. Disruption of the NF- $\kappa \mathrm{B} / \mathrm{NLRP} 3$ connection by melatonin requires retinoidrelated orphan receptor- $\alpha$ and blocks the septic response in mice. FASEB J. (2015) 29:3863-75. doi: 10.1096/fj.15-273656

22. Park JS, Lim MA, Cho ML, Ryu JG, Moon YM, Jhun JY, et al. p53 controls autoimmune arthritis via STAT-mediated regulation of the Th17 cell/Treg cell balance in mice. Arthritis Rheum. (2013) 65:949-59. doi: 10.1002/art.37841

23. Bettan M, Emmanuel F, Darteil R, Caillaud JM, Soubrier F, Delaere P, et al. High-level protein secretion into blood circulation after electric pulse-mediated gene transfer into skeletal muscle. Mol Ther. (2000) 2:20410. doi: 10.1006/mthe.2000.0117

24. Barnett ML, Kremer JM, St Clair EW, Clegg DO, Furst D, Weisman $M$, et al. Treatment of rheumatoid arthritis with oral type II collagen. Results of a multicenter, double-blind, placebo-controlled trial. Arthritis Rheum. (1998) 41:2907. doi: 10.1002/1529-0131(199802)41:2<290::AID-ART13>3.0.CO;2-R

25. Park JS, Kwok SK, Lim MA, Oh HJ, Kim EK, Jhun JY, et al. TWEAK promotes osteoclastogenesis in rheumatoid arthritis. Am J Pathol. (2013) 183:857-67. doi: 10.1016/j.ajpath.2013.05.027

26. Kallen J, Schlaeppi JM, Bitsch F, Delhon I, Fournier B. Crystal structure of the human $\operatorname{ROR} \alpha$ Ligand binding domain in complex with cholesterol sulfate at 2.2 A. J Biol Chem. (2004) 279:14033-8. doi: 10.1074/jbc.M400302200

27. Kim EJ, Yoo YG, Yang WK, Lim YS, Na TY, Lee IK, et al. Transcriptional activation of HIF-1 by ROR $\alpha$ and its role in hypoxia signaling. Arterioscler
Thromb Vasc Biol. (2008) 28:1796-802. doi: 10.1161/ATVBAHA.108. 171546

28. Kim EJ, Yoon YS, Hong S, Son HY, Na TY, Lee MH, et al. Retinoic acid receptor-related orphan receptor $\alpha$-induced activation of adenosine monophosphate-activated protein kinase results in attenuation of hepatic steatosis. Hepatology. (2012) 55:1379-88. doi: 10.1002/hep.25529

29. Bitsch F, Aichholz R, Kallen J, Geisse S, Fournier B, Schlaeppi JM. Identification of natural ligands of retinoic acid receptorrelated orphan receptor alpha ligand-binding domain expressed in Sf9 cells-a mass spectrometry approach. Anal Biochem. (2003) 323:139-49. doi: 10.1016/j.ab.2003.08.029

30. Yang XO, Panopoulos AD, Nurieva R, Chang SH, Wang D, Watowich SS, et al. STAT3 regulates cytokine-mediated generation of inflammatory helper T cells. J Biol Chem. (2007) 282:9358-63. doi: 10.1074/jbc.C600321200

31. Durant L, Watford WT, Ramos HL, Laurence A, Vahedi G, Wei L, et al. Diverse targets of the transcription factor STAT3 contribute to $\mathrm{T}$ cell pathogenicity and homeostasis. Immunity. (2010) 32:60515. doi: 10.1016/j.immuni.2010.05.003

32. Wang Y, Solt LA, Kojetin DJ, Burris TP. Regulation of p53 stability and apoptosis by a ROR agonist. PLOS ONE. (2012) 7:e34921. doi: 10.1371/journal.pone.0034921

33. McInnes IB, Buckley CD, Isaacs JD. Cytokines in rheumatoid arthritis shaping the immunological landscape. Nat Rev Rheumatol. (2016) 12:638. doi: 10.1038/nrrheum.2015.171

34. Choy E. Understanding the dynamics: pathways involved in the pathogenesis of rheumatoid arthritis. Rheumatology. (2012) 51(Suppl 5):v3-11. doi: 10.1093/rheumatology/kes113

35. Marrelli A, Cipriani P, Liakouli V, Carubbi F, Perricone C, Perricone R, et al. Angiogenesis in rheumatoid arthritis: a disease specific process or a common response to chronic inflammation? Autoimmun Rev. (2011) 10:5958. doi: 10.1016/j.autrev.2011.04.020

36. Choi ST, Kim JH, Seok JY, Park YB, Lee SK. Therapeutic effect of antivascular endothelial growth factor receptor I antibody in the established collagen-induced arthritis mouse model. Clin Rheumatol. (2009) 28:3337. doi: 10.1007/s10067-008-1075-x

37. Grosios K, Wood J, Esser R, Raychaudhuri A, Dawson J. Angiogenesis inhibition by the novel VEGF receptor tyrosine kinase inhibitor, PTK787/ZK222584, causes significant anti-arthritic effects in models of rheumatoid arthritis. Inflamm Res. (2004) 53:133-42. doi: 10.1007/s00011-003-1230-4

38. Yoo SA, Yoon HJ, Kim HS, Chae CB, De Falco S, Cho CS, et al. Role of placenta growth factor and its receptor flt-1 in rheumatoid inflammation: a link between angiogenesis and inflammation. Arthritis Rheum. (2009) 60:34554. doi: 10.1002/art.24289

39. Gravallese EM. Bone destruction in arthritis. Ann Rheum Dis. (2002) 61 (Suppl 2):ii84-6. doi: 10.1136/ard.61.suppl_2.ii84

40. O'Gradaigh D, Ireland D, Bord S, Compston JE. Joint erosion in rheumatoid arthritis: interactions between tumour necrosis factor alpha, interleukin 1 , and receptor activator of nuclear factor kappaB ligand (RANKL) regulate osteoclasts. Ann Rheum Dis. (2004) 63:354-9. doi: 10.1136/ard.2003. 008458

41. Meyer T, Kneissel M, Mariani J, Fournier B. In vitro and in vivo evidence for orphan nuclear receptor RORalpha function in bone metabolism. Proc Natl Acad Sci USA. (2000) 97:9197-202. doi: 10.1073/pnas.150246097

42. Giguere V, Tini M, Flock G, Ong E, Evans RM, Otulakowski G. Isoformspecific amino-terminal domains dictate DNA-binding properties of ROR alpha, a novel family of orphan hormone nuclear receptors. Genes Dev. (1994) 8:538-53. doi: 10.1101/gad.8.5.538

43. Medvedev A, Yan ZH, Hirose T, Giguere V, Jetten AM. Cloning of a cDNA encoding the murine orphan receptor RZR/ROR gamma and characterization of its response element. Gene. (1996) 181:199206. doi: 10.1016/S0378-1119(96)00504-5

44. Lau P, Bailey P, Dowhan DH, Muscat GE. Exogenous expression of a dominant negative RORalpha1 vector in muscle cells impairs differentiation: RORalpha1 directly interacts with p300 and myoD. Nucleic Acids Res. (1999) 27:41120. doi: 10.1093/nar/27.2.411

45. Migita H, Satozawa N, Lin JH, Morser J, Kawai K. RORalphal and RORalpha4 suppress TNF-alpha-induced VCAM-1 and 
ICAM-1 expression in human endothelial cells. FEBS Lett. (2004) 557:269-74. doi: 10.1016/S0014-5793(03)01502-3

46. Han YH, Kim HJ, Kim EJ, Kim KS, Hong S, Park HG, et al. RORalpha decreases oxidative stress through the induction of SOD2 and GPx1 expression and thereby protects against nonalcoholic steatohepatitis in mice. Antioxid Redox Signal. (2014) 21:2083-94. doi: 10.1089/ars.2013.5655

47. Kim H, Lee JM, Lee G, Bhin J, Oh SK, Kim K, et al. DNA damage-induced ROR $\alpha$ is crucial for p53 stabilization and increased apoptosis. Mol Cell. (2011) 44:797-810. doi: 10.1016/j.molcel.2011.09.023

48. Jetten AM. Recent advances in the mechanisms of action and physiological functions of the retinoid-related orphan receptors (RORs). Curr Drug Targets Inflamm Allergy. (2004) 3:395-412. doi: 10.2174/1568010042634497

49. Xiao L, Zhang Z, Luo X, Yang H, Li F, Wang N. Retinoid acid receptor-related orphan receptor alpha $(\operatorname{ROR} \alpha)$ regulates macrophage M2 polarization via activation of AMPKalpha. Mol Immunol. (2016) 80:1723. doi: 10.1016/j.molimm.2016.10.006

50. Liu J, Liu X, Xiong XQ, Yang T, Cui T, Hou NL, et al. Effect of vitamin A supplementation on gut microbiota in children with autism spectrum disorders - a pilot study. BMC Microbiol. (2017) 17:204. doi: 10.1186/s12866-017-1096-1

51. Farez MF, Mascanfroni ID, Mendez-Huergo SP, Yeste A, Murugaiyan G, Garo LP, et al. Melatonin contributes to the seasonality of multiple sclerosis relapses. Cell. (2015) 162:1338-52. doi: 10.1016/j.cell.2015.08.025

52. Fox CJ, Hammerman PS, Thompson CB. Fuel feeds function: energy metabolism and the T-cell response. Nat Rev Immunol. (2005) 5:844-52. doi: $10.1038 /$ nri1710
53. Jones RG, Thompson CB. Revving the engine: signal transduction fuels $\mathrm{T}$ cell activation. Immunity. (2007) 27:173-8. doi: 10.1016/j.immuni.2007. 07.008

54. Jones RG, Bui T, White C, Madesh M, Krawczyk CM, Lindsten T, et al. The proapoptotic factors Bax and Bak regulate $\mathrm{T}$ cell proliferation through control of endoplasmic reticulum $\mathrm{Ca}(2+)$ homeostasis. Immunity. (2007) 27:268-80. doi: 10.1016/j.immuni.2007.05.023

55. Vander Heiden MG, Cantley LC, Thompson CB. Understanding the Warburg effect: the metabolic requirements of cell proliferation. Science. (2009) 324:1029-33. doi: 10.1126/science.1160809

56. Michalek RD, Gerriets VA, Jacobs SR, Macintyre AN, MacIver NJ, Mason EF, et al. Cutting edge: distinct glycolytic and lipid oxidative metabolic programs are essential for effector and regulatory CD4+ T cell subsets. J Immunol. (2011) 186:3299-303. doi: 10.4049/jimmunol.1003613

Conflict of Interest: The authors declare that the research was conducted in the absence of any commercial or financial relationships that could be construed as a potential conflict of interest.

Copyright (C) 2019 Park, Moon, Lim, Byun, Hwang, Yang, Kim, Lee, Kim, Lee, Kwok, Min, Lee, Shin, Park and Cho. This is an open-access article distributed under the terms of the Creative Commons Attribution License (CC BY). The use, distribution or reproduction in other forums is permitted, provided the original author(s) and the copyright owner(s) are credited and that the original publication in this journal is cited, in accordance with accepted academic practice. No use, distribution or reproduction is permitted which does not comply with these terms. 